\title{
Sb-Containing Metal Oxide Catalysts for the Selective Catalytic Reduction of $\mathrm{NO}_{x}$ with $\mathrm{NH}_{3}$
}

\author{
Qian Xu ${ }^{1}$, Dandan Liu ${ }^{1}$, Chuchu Wang ${ }^{1}$, Wangcheng Zhan ${ }^{1}$, Yanglong Guo ${ }^{1} \mathbb{D}$, Yun Guo ${ }^{1}$, \\ Li Wang ${ }^{1, *}$, Qingping $\mathrm{Ke}^{2}$ and Minh Ngoc $\mathrm{Ha}^{3}$ D \\ 1 Key Laboratory for Advanced Materials and Research Institute of Industrial Catalysis, School of Chemistry \\ \& Molecular Engineering, East China University of Science and Technology, 130 Meilong Road, \\ Shanghai 200237, China; Y11140023@mail.ecust.edu.cn (Q.X.); Y30181049@mail.ecust.edu.cn (D.L.); \\ wangyongchuchu@163.com (C.W.); zhanwc@ecust.edu.cn (W.Z.); ylguo@ecust.edu.cn (Y.G.); \\ yunguo@ecust.edu.cn (Y.G.) \\ 2 College of Chemistry and Chemical Engineering, Anhui University of Technology, Maanshan 243002, China; \\ Qingke@ahut.edu.cn \\ 3 VNU Key Laboratory of Advanced Material for Green Growth, VNU University of Science, \\ Vietnam National University, Hanoi 100000, Vietnam; haminhngoc@hus.edu.vn \\ * Correspondence: wangli@ecust.edu.cn
}

Received: 30 August 2020; Accepted: 30 September 2020; Published: 8 October 2020

\begin{abstract}
Sb-containing catalysts $\left(\mathrm{SbZrO}_{x}(\mathrm{SbZr}), \mathrm{SbCeO}_{x}(\mathrm{SbCe}), \mathrm{SbCeZrO}_{x}(\mathrm{SbCeZr})\right)$ were prepared by citric acid method and investigated for the selective catalytic reduction (SCR) of $\mathrm{NO}_{x}$ with $\mathrm{NH}_{3}$ $\left(\mathrm{NH}_{3}\right.$-SCR). SbCeZr outperformed $\mathrm{SbZr}$ and $\mathrm{SbCe}$ and exhibited the highest activity with $80 \%$ $\mathrm{NO}$ conversion in the temperature window of $202-422{ }^{\circ} \mathrm{C}$. Meanwhile, it also had good thermal stability and resistance against $\mathrm{H}_{2} \mathrm{O}$ and $\mathrm{SO}_{2}$. Various characterization methods, such as XRD, XPS, $\mathrm{H}_{2}$-TPR, $\mathrm{NH}_{3}$-TPD, and in situ diffuse reflectance infrared Fourier transform (DRIFT), were applied to understand their different behavior in $\mathrm{NO}_{x}$ removal. The presence of $\mathrm{Sb}$ in the metal oxides led to the difference in acid distribution and redox property, which closely related with the $\mathrm{NH}_{3}$ adsorption and NO oxidation. Brønsted acid and Lewis acid were evenly distributed on SbCe, while Brønsted acid dominated on SbCeZr. Compared with Brønsted acid, Lewis acid was slightly active in $\mathrm{NH}_{3}-\mathrm{SCR}_{\text {. }}$ The competition between $\mathrm{NH}_{3}$ adsorption and $\mathrm{NO}$ oxidation was dependent on $\mathrm{SbO}_{x}$ and metal oxides, which were found on SbCe while not on SbCeZr.
\end{abstract}

Keywords: SbCeZr; $\mathrm{NH}_{3}-\mathrm{SCR}$; active sites; mechanism

\section{Introduction}

Nitrogen oxide $\left(\mathrm{NO}_{x}\right)$, one of the main environmental contaminants emitted from stationary sources and mobile sources, causes photochemical smog, acid rain, and the depletion of the ozone layer [1,2]. Several technologies have been proposed for $\mathrm{NO}_{x}$ removal, such as direct decomposition of $\mathrm{NO}_{x}, \mathrm{NO}_{x}$ storage reduction (NSR), and the selective catalytic reduction (SCR) process with ammonia $\left(\mathrm{NH}_{3}-\mathrm{SCR}\right)$ or hydrocarbons (HC-SCR). The $\mathrm{NH}_{3}-\mathrm{SCR}$ process has been proven to be the efficient method to satisfy the restrict regulations of $\mathrm{NO}_{x}$ emissions [3]. In general, the $\mathrm{NH}_{3}-\mathrm{SCR}$ reaction is a competitive process between $\mathrm{NH}_{3}$ oxidation and $\mathrm{NO}_{x}$ reduction, which are closely affected by reaction temperature. The enhanced oxidation activity at low temperature promotes $\mathrm{NO}_{x}$ selective reduction, while it also takes a risk for the depletion of $\mathrm{NH}_{3}$ at high temperature leading to the decrease in NO reduction. Meanwhile, the reaction thermal shock and exhaust components $\left(\mathrm{H}_{2} \mathrm{O}\right.$ and $\left.\mathrm{SO}_{2}\right)$ put forward strict requirements on the design of $\mathrm{NH}_{3}-\mathrm{SCR}$ catalysts.

$\mathrm{CeO}_{2}$ possesses unique oxygen storage-release capability by the formation of $\mathrm{Ce}^{3+} / \mathrm{Ce}^{4+}$ redox couples [4], but the maximum $\mathrm{NO}$ conversion on $\mathrm{CeO}_{2}$ was about $30 \%$ in the whole temperature 
range. Compared with mono-metal oxides, dual metal oxides have been more active in NO abatement. The presence of $\mathrm{Ti}, \mathrm{W}, \mathrm{Mo}, \mathrm{Mn}$, and $\mathrm{Nb}$ can efficiently broaden the temperature window, especially the introduction of W. Nearly $100 \% \mathrm{NO}_{x}$ conversion could be achieved on $\mathrm{CeWO}_{x}$ in a wide temperature range $\left(250-425^{\circ} \mathrm{C}\right)$ under a rather high gas hourly space velocity (GHSV) $\left(500,000 \mathrm{~h}^{-1}\right)$. The effects of $\mathrm{SO}_{2}$ on the SCR over $\mathrm{CeO}_{2}$ was strongly dependent on the $\mathrm{SO}_{2}$ content and reaction conditions. An appropriate level for sulfated pretreatment can promote $\mathrm{SCR}$, and the presence of excess $\mathrm{SO}_{2}$ shows obvious negative effects. $\mathrm{Li}$ studied that $\mathrm{SO}_{2}$ was preferentially bonded with $\mathrm{CeO}_{2}$ as sulfate species leading to a significant decrease in reducibility and the loss of surface active oxygen groups [5]. Suitable sulfation promoted $\mathrm{NH}_{3}$ adsorption and favored the formation of oxygen vacancies which facilitated $\mathrm{NH}_{3}$-SCR [6]. Hong's research indicated that the optimal condition for sulfation treatment was $800 \mathrm{ppm} \mathrm{SO} \mathrm{S}_{2} \mathrm{~h}$ at $500{ }^{\circ} \mathrm{C}$ [7]. Meanwhile, the thermal stability of the sulfated Ce-based catalyst needs to be further improved [8].

$\mathrm{Sb}$ compounds are generally classified into the valences of +3 and +5 , in which the oxidation state of +5 is more stable. The Sb-containing oxides are $\mathrm{Sb}_{2} \mathrm{O}_{3}, \mathrm{Sb}_{2} \mathrm{O}_{5}$, and mixed oxide $\mathrm{Sb}_{2} \mathrm{O}_{4}$ that is composed of $\mathrm{Sb}^{3+}$ and $\mathrm{Sb}^{5+}$ [9]. $\mathrm{Sb}$ has been widely used as a promoter for $\mathrm{NH}_{3}-\mathrm{SCR}$ catalysts [6,7]. The surface acid and the redox capability are generally considered to be two necessary factors for $\mathrm{NH}_{3}$-SCR catalysts [10-12]. The addition of $\mathrm{Sb}$ can improve the dispersion of active species [13] and increase acid sites and the redox property [14], which are due to the strong interaction between $\mathrm{SbO}_{x}$ and other metal oxides $[15,16]$. Besides the promotion in activity, the resistance of $\mathrm{K}_{2} \mathrm{O}$ poisoning [17] and $\mathrm{SO}_{2}$ are also found [18] in Sb-containing catalysts. The role of $\mathrm{Sb}$ as a promoter reflects in minimizing the binding affinity between the catalytic surface and the ammonium (bi)sulfates species, which is beneficial for the low-temperature $\mathrm{SO}_{2}$ resistance [19].

The substitution of $\mathrm{Ce}^{4+}$ by $\mathrm{Zr}^{4+}$ helps create structural defect, accelerating oxygen diffusion and the formation of surface oxygen species [20], which can consequently promote the redox property [21,22]. $\mathrm{CeZrO}_{x}$ mixed oxide with remarkable thermal stability shows an enormous advantage in $\mathrm{NH}_{3}-$ SCR $[23,24]$. In this study, Sb-containing metal oxides ( $\mathrm{SbZr}$, SbCe, SbCeZr) were prepared by citric acid method and investigated for $\mathrm{NO}_{x}$ removal by $\mathrm{NH}_{3}-\mathrm{SCR}$. The SbCeZr exhibited higher catalytic activity than $\mathrm{SbCe}$ and $\mathrm{SbZr}$ catalysts, especially in the presence of $\mathrm{H}_{2} \mathrm{O}$ and $\mathrm{SO}_{2}$. The correlation between physicochemical properties and SCR performance was explored by various characterization techniques, and the mechanism was also studied using in situ diffuse reflectance infrared Fourier transform spectroscopy (DRIFT).

\section{Results and Discussion}

\subsection{Catalyst Activity}

\subsection{1. $\mathrm{NH}_{3}$-SCR Performance}

$\mathrm{NO}_{x}$ conversions over the catalysts as a function of temperature are illustrated in Figure 1a. Pristine $\mathrm{SbO}_{x}$ and $\mathrm{SbZr}$ showed negligible catalytic activity with $\mathrm{NO}_{x}$ conversion below $10 \%$ in the whole temperature range. Even for $\mathrm{CeO}_{2}$, the maximum $\mathrm{NO}_{x}$ conversion was only $29 \%$ at $360{ }^{\circ} \mathrm{C}$. The addition of $\mathrm{Sb}$ promoted the $\mathrm{NO}_{x}$ conversion over Ce-containing catalysts, and SbCeZr exhibited better $\mathrm{NH}_{3}$-SCR performance than SbCe. The temperature for $50 \%$ conversion $\left(\mathrm{T}_{50}\right)$ was $175{ }^{\circ} \mathrm{C}$ over $\mathrm{SbCeZr}$, which was lower than that of $\mathrm{SbCe}\left(223^{\circ} \mathrm{C}\right)$. The operation temperature window $\left(\mathrm{NO}_{x}\right.$ conversion over $80 \%$ ) was $202-422{ }^{\circ} \mathrm{C}$ over SbCeZr, while it was $261-407^{\circ} \mathrm{C}$ over $\mathrm{SbCe}$. 


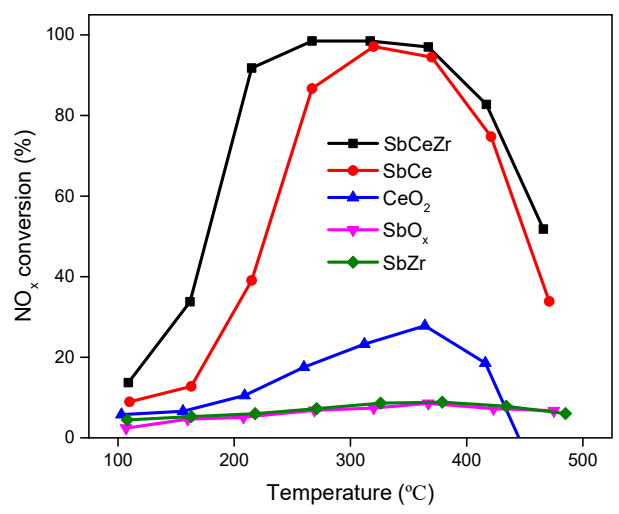

(a)

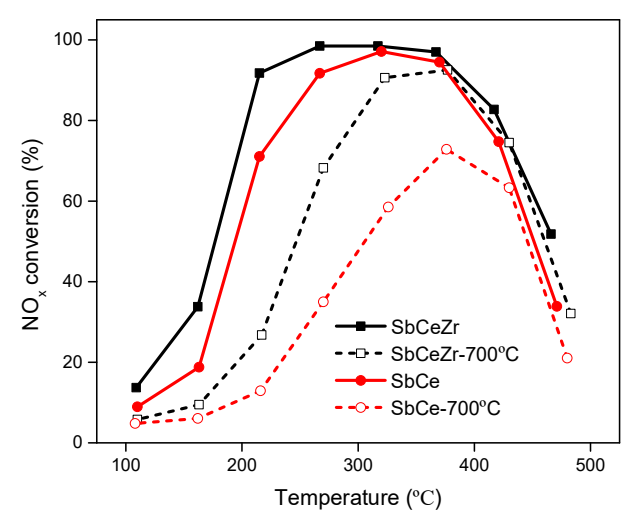

(b)

Figure 1. (a) $\mathrm{NO}_{x}$ conversions and (b) thermal stability over the catalysts (reaction conditions: $500 \mathrm{ppm}$ $\mathrm{NO}, 500$ ppm $\mathrm{NH}_{3}, 5 \% \mathrm{O}_{2}$, with Ar balance).

The apparent activation energy of the $\mathrm{NH}_{3}-\mathrm{SCR}$ reaction is an important factor to evaluate the role and efficiency of the catalyst in the reaction [25]. By calculating the reaction rate constant of the $\mathrm{NH}_{3}$-SCR reaction over $\mathrm{SbCeZr}$ and $\mathrm{SbCe}$, the apparent activation energy of the catalysts were obtained. The reaction activation energy over the SbCeZr catalyst $(33.3 \mathrm{~kJ} / \mathrm{mol})$ was lower than that of the SbCe catalyst $(42.1 \mathrm{~kJ} / \mathrm{mol})$, which further confirmed the excellent $\mathrm{NH}_{3}-\mathrm{SCR}$ reaction performance of $\mathrm{SbCeZr}$.

In order to investigate the thermal stability of $\mathrm{SbCeZr}$ and SbCe, the catalysts were aged at $700{ }^{\circ} \mathrm{C}$ for $4 \mathrm{~h}$ in the air before testing. As shown in Figure 1b, aging had a side effect on catalytic activity, which led to the loss in activity and shrink from the operation temperature window. The presence of $\mathrm{Zr}$ improved the thermal resistance of thermal shock. $\mathrm{T}_{50}$ of aged SbCeZr turned out to be $247^{\circ} \mathrm{C}$ and the operation temperature window narrowed to $300-413{ }^{\circ} \mathrm{C}$, resulting from the sintering. The maximum $\mathrm{NO}_{x}$ conversion over aged SbCe was only $73 \%$ at $373{ }^{\circ} \mathrm{C}$, i.e., aging led to the significant deactivation.

\subsubsection{Effects of $\mathrm{H}_{2} \mathrm{O}$ and $\mathrm{SO}_{2}$}

$\mathrm{SO}_{2}$ and $\mathrm{H}_{2} \mathrm{O}$ are unavoidable in the feed gas, so the effect on the catalytic activities over SbCeZr and $\mathrm{SbCe}$ were investigated. As shown in Figure $2 \mathrm{a}$, the $\mathrm{NH}_{3}-\mathrm{SCR}$ performance of $\mathrm{SbCeZr}$ was slightly affected by $\mathrm{SO}_{2}$ or $\mathrm{H}_{2} \mathrm{O}$ at temperatures below $220^{\circ} \mathrm{C}$. However, the presence of $\mathrm{H}_{2} \mathrm{O}$ significantly reduced the catalytic activity at temperatures above $420^{\circ} \mathrm{C}$, which could be attributed to the competitive adsorption between $\mathrm{H}_{2} \mathrm{O}$ and $\mathrm{NH}_{3}$ [26,27]. In the presence of $\mathrm{O}_{2}$ and $\mathrm{SO}_{2}$, the deposited sulfates on the catalysts led to the decrease of the specific surface area (SSA) [28] and blocked the active sites at low temperature [29]. With increased temperature, the decomposition of sulfates led to the restoration of active sites [30]. The presence of $\mathrm{H}_{2} \mathrm{O}$ facilitated $\mathrm{SO}_{2}$ oxidation at low temperature and inhibited sulfate decomposition at high temperature. Therefore, the presence of $\mathrm{H}_{2} \mathrm{O}$ and $\mathrm{SO}_{2}$ had a more detrimental effect than $\mathrm{H}_{2} \mathrm{O}$ or $\mathrm{SO}_{2}$.

The presence of $\mathrm{SO}_{2}$ on $\mathrm{SbCe}$ had an influence similar to that on SbCeZr. Unfortunately, the presence of $\mathrm{H}_{2} \mathrm{O}$ had a detrimental effect on $\mathrm{NH}_{3}-\mathrm{SCR}$ performance over SbCe. The light-off temperature $\left(\mathrm{T}_{50}\right)$ shifted to $284{ }^{\circ} \mathrm{C}$, and the maximum $\mathrm{NO}_{x}$ conversion was only $66 \%$ at $370{ }^{\circ} \mathrm{C}$. When both $\mathrm{H}_{2} \mathrm{O}$ and $\mathrm{SO}_{2}$ were introduced simultaneously, the synergy effect made the $\mathrm{NH}_{3}-\mathrm{SCR}$ performance drop even more. $\mathrm{T}_{50}$ shifted to high temperature and the maximum $\mathrm{NO}_{x}$ conversion also decreased accordingly. The decrease of $\mathrm{NH}_{3}-\mathrm{SCR}$ performance was not only related to the formation of ammonium salt on the catalyst surface but also connected with the fact that the active phase was sulfated and then formed stable sulfate species [31]. 


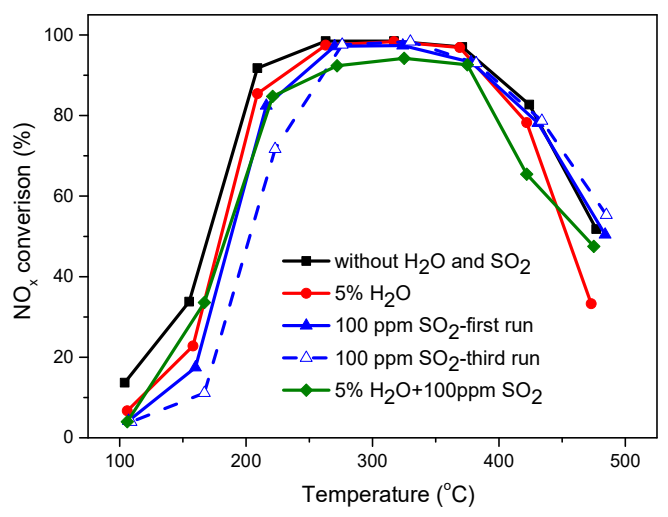

(a)

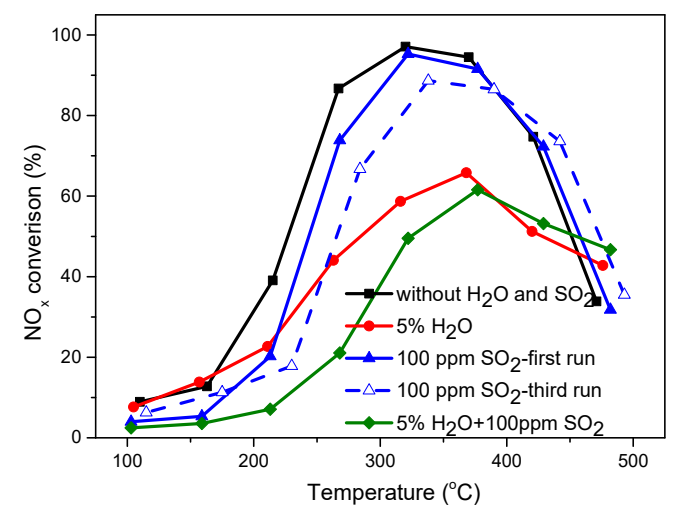

(b)

Figure 2. Effect of $\mathrm{H}_{2} \mathrm{O}$ and $\mathrm{SO}_{2}$ on the $\mathrm{NH}_{3}$-SCR performance over (a) the SbCeZr catalyst and (b) the SbCe catalyst (reaction conditions: 500 ppm NO, 500 ppm NH $3,5 \% \mathrm{O}_{2}, 5 \% \mathrm{H}_{2} \mathrm{O}, 100 \mathrm{ppm} \mathrm{SO}_{2}$, with Ar balance).

Furthermore, repeated temperature ramps (three times) containing $\mathrm{SO}_{2}$ over the $\mathrm{SbCeZr}$ catalyst and the SbCe catalyst were also conducted. For SbCeZr, the second time was consistent with the third time, and slightly less active than the first time below $250{ }^{\circ} \mathrm{C}$. It suggests that $\mathrm{SbCeZr}$ had a better performance of resistance to $\mathrm{SO}_{2}$. For $\mathrm{SbCe}$, during the three test ramps, the $\mathrm{T}_{80}$ kept shifting to higher temperatures, which narrowed the operation window.

\subsection{Catalyst Characterization}

\subsubsection{XRD}

The XRD patterns of the fresh and aging catalysts are shown in Figure 3. The XRD patterns of $\mathrm{CeO}_{2}$ and $\mathrm{ZrO}_{2}$ showed sharp diffraction peaks corresponding to $\mathrm{CeO}_{2}$ with a cubic fluorite structure (JCPDS 34-0394, $2 \theta=28.6^{\circ}, 47.5^{\circ}$, and 56.4 ${ }^{\circ}$ ) and tetrahedral $\mathrm{ZrO}_{2}\left(\mathrm{JCPDS} 50-1089,2 \theta=30.1^{\circ}, 50.4^{\circ}\right.$, and $60.0^{\circ}$ ). The typical peaks at $19.8^{\circ}, 25.7^{\circ}$, and $29.0^{\circ}$ over $\mathrm{SbO}_{x}$ were observed and assigned to $\mathrm{Sb}_{2} \mathrm{O}_{4}$ (JCPDS 11-0694). Compared with the XRD pattern of $\mathrm{CeO}_{2}$, the diffraction peaks of CeZr shifted to high angles, suggesting that $\mathrm{Zr}$ was incorporated into the $\mathrm{CeO}_{2}$ crystal lattice to form a $\mathrm{CeZrO}_{4}$ solid solution.

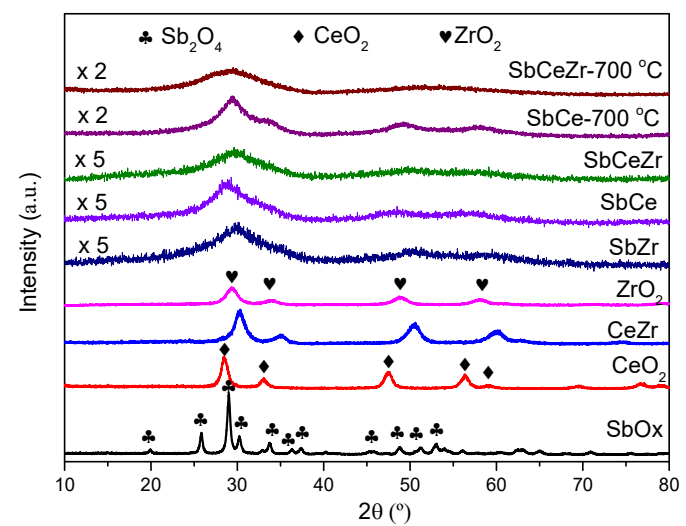

Figure 3. XRD patterns of the catalysts.

With the introduction of $\mathrm{Sb}$, the diffraction peaks were broadened and weakened, which led to the absence of obvious peaks. No diffraction peaks related to $\mathrm{SbO}_{x}$ were detected, and a completely amorphous structure was formed on the Sb-containing catalysts. Compared with the fresh samples, 
the diffraction peaks of aged catalysts (aging at $700{ }^{\circ} \mathrm{C}$ in air for $4 \mathrm{~h}$ ) intensified, indicating the increase in the grain size.

According to Table 1, the specific surface area (SSA) of SbCeZr $\left(73 \mathrm{~m}^{2} / \mathrm{g}\right)$ was slightly higher than that of SbCe $\left(68 \mathrm{~m}^{2} / \mathrm{g}\right)$. Combining the value of specific surface area (Table 1) with activity showed that specific surface area was not the decisive factor in catalyst activity. It thus suggested that other factors were affecting activity. The loss of SSA was found after aging, especially on SbCe. The SSA of SbCe- $700{ }^{\circ} \mathrm{C}$ was only $9 \mathrm{~m}^{2} / \mathrm{g}$, which was only $13 \%$ of fresh SbCe. However, $57 \%$ SSA of SbCeZr was lost after aging. Combining the results of XRD and SSA showed that SbCeZr possessed the higher thermal stability as compared to SbCe.

Table 1. Brunauer-Emmett-Teller (BET) specific surface area (SSA), bulk phase, and surface atom concentration of the catalysts.

\begin{tabular}{|c|c|c|c|c|c|c|}
\hline \multirow{2}{*}{ Sample } & \multirow{2}{*}{$\mathrm{S}_{\mathrm{BET}}\left(\mathrm{m}^{2} / \mathrm{g}\right)^{\mathrm{a}}$} & \multirow{2}{*}{$\mathrm{Sb} /(\mathrm{Ce}+\mathrm{Zr})^{b}$} & \multicolumn{4}{|c|}{ Surface Atom Concentration (\%) ${ }^{c}$} \\
\hline & & & $\mathrm{Sb} /(\mathrm{Ce}+\mathrm{Zr})$ & $\mathrm{Sb}^{5+} / \mathrm{Sb}$ & $\mathrm{Ce}^{3+} / \mathrm{Ce}$ & $\mathrm{O}_{\alpha} /\left(\mathrm{O}_{\alpha}+\mathrm{O}_{\beta}\right)$ \\
\hline $\mathrm{SbO}_{x}$ & - & - & - & 50.3 & - & 38.1 \\
\hline $\mathrm{SbZr}$ & 32 & 0.68 & 1.09 & 55.3 & - & 33.4 \\
\hline $\mathrm{SbCe}$ & 68 & 1.02 & 1.59 & 62.2 & 32.9 & 40.6 \\
\hline $\mathrm{SbCeZr}$ & 73 & 0.57 & 0.66 & 64.3 & 42.1 & 47.8 \\
\hline
\end{tabular}

${ }^{a}$ Specific surface area determined by $\mathrm{N}_{2}$ adsorption-desorption. ${ }^{\mathrm{b}} \mathrm{Sb} /(\mathrm{Ce}+\mathrm{Zr})$ mole ratio detected by ICP-AES.

c Surface atom concentration detected by XPS analysis.

\subsubsection{XPS}

Figure 4 presented the XPS spectra of Sb 3d, Ce 3d, and O 1s for Sb-containing catalysts, and the surface atom concentration and chemical state are summarized in Table 1. For the SbCeZr catalyst, the bulk phase mole ratio of $\mathrm{Sb} /(\mathrm{Ce}+\mathrm{Zr})$ was 0.57 , slightly lower than the surface atom concentration ratio 0.66 . However, as for the SbCe catalyst and SbZr catalyst, the bulk phase mole ratio was much lower than the surface concentration. These results indicated that more $\mathrm{Sb}$ existed on the surface of $\mathrm{CeO}_{2}$ and $\mathrm{ZrO}_{2}$ over $\mathrm{SbCe}$ and $\mathrm{SbZr}$, while more $\mathrm{Sb}$ was incorporated into the $\mathrm{CeZrO}_{x}$.

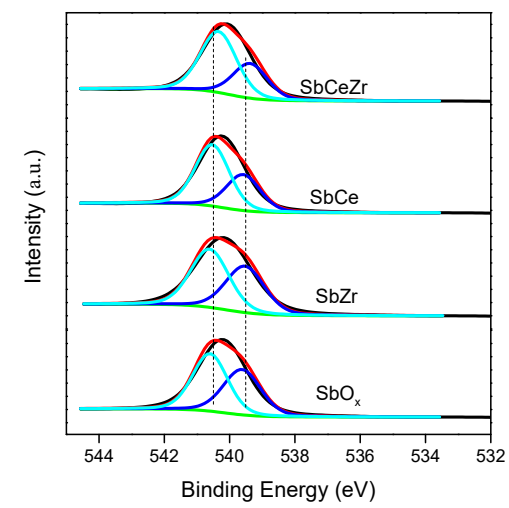

(a)

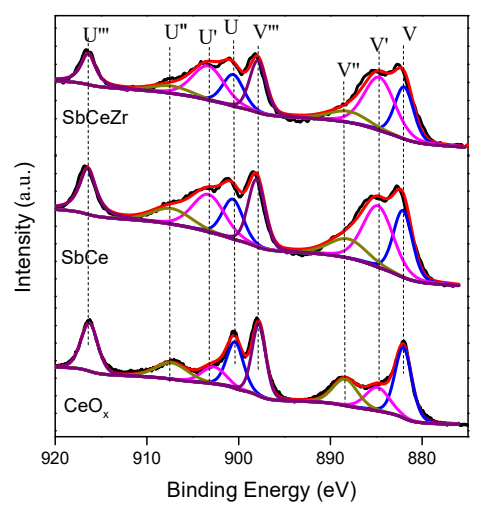

(b)

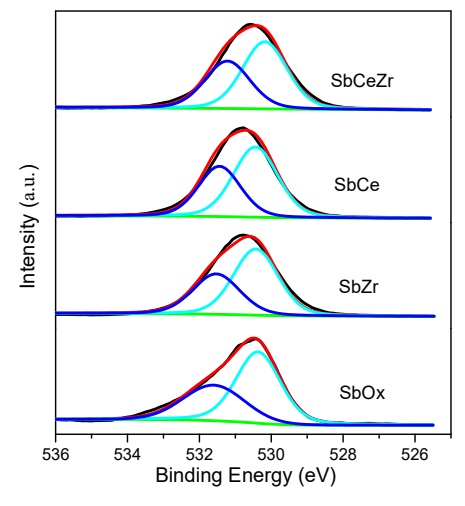

(c)

Figure 4. XPS spectra for (a) Sb3d, (b) Ce3d, and (c) O1s over the catalysts.

Figure 4a showed the $\mathrm{Sb}_{3} \mathrm{~d}_{3 / 2}$ spectra of $\mathrm{Sb}$-containing catalysts and $\mathrm{SbO}_{x}$. Because of the $\mathrm{O} 1 \mathrm{~s}$ and $\mathrm{Sb} 3 \mathrm{~d}_{5 / 2}$ photoemission line overlapping around $530.0 \mathrm{eV}$, the $\mathrm{Sb}_{3 / 2}$ spectra at higher binding energy were used. This peak could be separated into two contributions- the Gaussian line centered at $540.4 \mathrm{eV}$ corresponds to antimony with an oxidation state of $\mathrm{Sb}^{5+}$, while the peak at $539.6 \mathrm{eV}$ corresponds to $\mathrm{Sb}^{3+}[9,16,32]$. As shown in Table 1, the proportion of $\mathrm{Sb}^{5+}$ increase followed the order of $\mathrm{SbO}_{x}<\mathrm{SbZr}$ $<\mathrm{SbCe}<\mathrm{SbCeZr}$. The ratio of $\mathrm{Sb}^{5+}$ over $\mathrm{SbO}_{x}$ was $50.3 \%$, meaning an equal proportion of $\mathrm{Sb}^{5+}$ and 
$\mathrm{Sb}^{3+}$, i.e., $\mathrm{Sb}_{2} \mathrm{O}_{4}$ was the main species in $\mathrm{SbO}_{x}$, which was in line with the $\mathrm{XRD}$ results. It was obvious that the concentration of $\mathrm{Sb}^{5+}$ over the $\mathrm{SbCeZr}$ was significantly improved to $64.3 \%$.

Figure $4 \mathrm{~b}$ presents the Ce $3 \mathrm{~d}$ spectra of the catalysts. The Ce $3 \mathrm{~d}$ peaks could be deconvoluted into four pairs of spin-orbit doublets. Four main peaks in $3 \mathrm{~d}_{5 / 2}$ at $881.9,884.9,887.8$, and $898.0 \mathrm{eV}$ were labeled as $V, V^{\prime}, V^{\prime \prime}$, and $V^{\prime \prime \prime}$, respectively. The four main peaks in $3 d_{3 / 2}$ at $900.8,903.0,907.4$, and $916.2 \mathrm{eV}$ were labeled as $\mathrm{U}^{\prime} \mathrm{U}^{\prime}, \mathrm{U}^{\prime \prime}$, and $\mathrm{U}^{\prime \prime \prime}$, respectively. The peaks labeled as $\mathrm{V}^{\prime}$ and $\mathrm{U}^{\prime}$ corresponded to $\mathrm{Ce}^{3+}$ and the other peaks labeled as $\mathrm{V}, \mathrm{V}^{\prime \prime}, \mathrm{V}^{\prime \prime}, \mathrm{U}, \mathrm{U}^{\prime \prime}$, and $\mathrm{U}^{\prime \prime}$ corresponded to $\mathrm{Ce}^{4+}[12,33]$. From the Ce 3d XPS spectra, it could be concluded that the $\mathrm{Ce}^{3+}$ and $\mathrm{Ce}^{4+}$ species coexisted in all the samples, and the ratios of $\mathrm{Ce}^{3+} /\left(\mathrm{Ce}^{4+}+\mathrm{Ce}^{3+}\right)$ of all the catalysts are listed in Table 1. The $\mathrm{Ce}^{3+} /\left(\mathrm{Ce}^{4+}+\mathrm{Ce}^{3+}\right)$ ratio over SbCeZr $(42.1 \%)$ was higher than that over $\mathrm{SbCe}(32.9 \%)$. The presence of $\mathrm{Sb}^{5+}$ led to the increase of the $\mathrm{Ce}^{3+}$ concentration due to the redox reaction $\mathrm{Sb}^{3+}+$ $\mathrm{Ce}^{4+} \leftrightarrow \mathrm{Sb}^{5+}+\mathrm{Ce}^{3+}$. The transformation of $\mathrm{Ce}^{4+}$ to $\mathrm{Ce}^{3+}$ created the charge imbalance and oxygen vacancy, facilitating the adsorption of oxygen species or activation of reactants in $\mathrm{NH}_{3}$-SCR [34].

The $\mathrm{O} 1 \mathrm{~s}$ spectra of all the catalysts are displayed in Figure 4c. The spectra were deconvoluted into two peaks. The peak at $530.2 \mathrm{eV}$ was attributed to lattice oxygen $\left(\mathrm{O}_{\beta}\right)$, and the other one at around $531.2 \mathrm{eV}$ was denoted to surface chemisorbed oxygen $\left(\mathrm{O}_{\alpha}\right)$. $\mathrm{O}_{\alpha}$ species usually correlated with oxygen defects or surface oxygen, such as $\mathrm{O}_{2}{ }^{2-}$ or $\mathrm{O}_{2}{ }^{-}$[35-37]. The relative ratios of $\mathrm{O}_{\alpha} /\left(\mathrm{O}_{\alpha}+\mathrm{O}_{\beta}\right)$ by peak deconvolution over the samples were $47.8 \%, 40.6 \%$, and $33.4 \%$ over $\mathrm{SbCeZr}$, SbCe, and SbZr, respectively, suggesting more surface chemisorbed oxygen formed over $\mathrm{SbCeZr}$.

\subsection{3. $\mathrm{H}_{2}-\mathrm{TPR}$}

The redox property of catalysts plays an important role in the $\mathrm{NH}_{3}-\mathrm{SCR}$ reaction $[37,38]$. Figure 5 shows the $\mathrm{H}_{2}$-TPR profiles of the catalysts. $\mathrm{CeO}_{2}$ showed two reduction peaks centered at 474 and $781{ }^{\circ} \mathrm{C}$, which were attributed to the reduction of surface oxygen and bulk oxygen of $\mathrm{CeO}_{2}$, respectively [22,39]. $\mathrm{SbO}_{x}$ also showed two reduction peaks centered at 616 and $701^{\circ} \mathrm{C}$, which could be ascribed to the reduction of $\mathrm{Sb}^{5+}$ to $\mathrm{Sb}^{3+}$ and $\mathrm{Sb}^{3+}$ to $\mathrm{Sb}^{0}$, respectively [9]. The reduction profiles of $\mathrm{SbZr}$ were similar to those of $\mathrm{SbO}_{x}$ with the reduction temperature shifting to lower temperature.

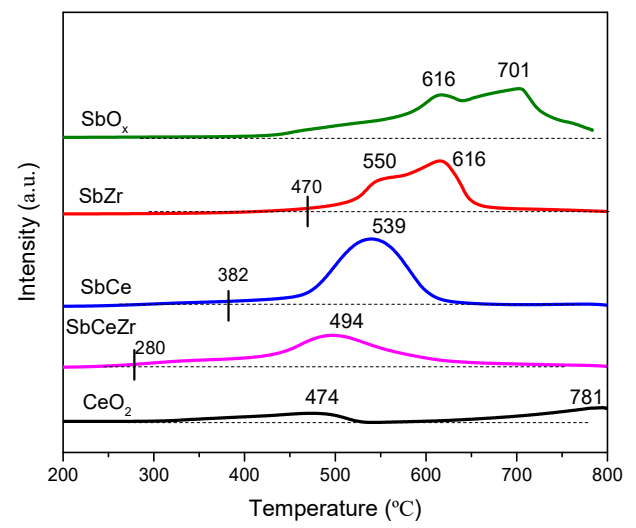

Figure 5. $\mathrm{H}_{2}$-TPR profiles of the catalysts.

The reduction behavior of $\mathrm{SbCe}$ and $\mathrm{SbCeZr}$ was different from that of $\mathrm{CeO}_{2}$ and $\mathrm{SbO}_{x}$. A broad peak was observed on SbCe and SbCeZr centered at $539{ }^{\circ} \mathrm{C}$ and $494^{\circ} \mathrm{C}$, respectively, which could be attributed to the combination of reduction peaks of $\mathrm{SbO}_{x}$ and $\mathrm{CeO}_{2}$ [40]. The broad reduction peak of $\mathrm{SbCeZr}$ shifted to lower $\mathrm{T}_{\text {onset }}$ (the onset reduction temperature of active oxygen) compared to the other catalysts ( $\mathrm{SbCe}$ and $\mathrm{SbZr}$ ). The lower reduction temperature of SbCeZr indicated the increase in redox and the generation of easily reducible species.

$\mathrm{H}_{2}$-TPR is usually used as a descriptor for the relative strength of the interaction among active components. The similar reduction profiles of $\mathrm{SbO}_{x}$ and $\mathrm{SbZr}$ suggested the rather weak interaction between $\mathrm{SbO}_{x}$ and $\mathrm{ZrO}_{2}$. However, a strong interaction was found on $\mathrm{SbCe}$ due to the co-reduction of 
$\mathrm{SbO}_{x}$ and $\mathrm{CeO}_{2}$, which also led to the higher reduction temperature. By contrast, with the help of $\mathrm{ZrO}_{2}$, the strong interaction between $\mathrm{SbO}_{x}$ and $\mathrm{CeO}_{2}$ was weakened, resulting in the lower onset reduction temperature of active oxygen.

\subsubsection{NO-TPD}

NO-TPD experiments were performed to investigate the adsorption and oxidation properties of $\mathrm{NO}_{x}$ on different catalysts. NO-TPD profiles and the calculated $\mathrm{NO}_{x}$ adsorption capacity are presented in Figure 6 and Table 2, respectively. The NO desorption peak below $100^{\circ} \mathrm{C}$ was attributed to physical adsorbed NO, and the one at about $260^{\circ} \mathrm{C}$ was attributed to chemical adsorbed NO [34]. Since the strength of $\mathrm{NO}$ bonding to the ceria surface depends on the reduction degree of support (unsaturated sites) [41], it could be concluded that the $\mathrm{Ce}^{3+}$ content on the SbCeZr surface was much higher than that of $\mathrm{SbCe}$, which was consistent with the XPS result.

Table 2. $\mathrm{H}_{2}$ consumption, $\mathrm{NH}_{3}$ desorption amount, and strong acid and $\mathrm{NO}_{x}$ adsorption capability of the catalysts.

\begin{tabular}{|c|c|c|c|c|c|c|}
\hline \multirow[t]{2}{*}{ Sample } & \multirow{2}{*}{$\underset{(\mathrm{mmol} / \mathrm{g})}{\mathrm{H}_{2} \text { Consumption }^{\mathrm{a}}}$} & \multicolumn{3}{|c|}{$\mathrm{NH}_{3}$-TPD Result ${ }^{b}$} & \multicolumn{2}{|c|}{$\begin{array}{c}\mathrm{NO}_{x} \text { Adsorption Capability } \\
(\mu \mathrm{mol} / \mathrm{g})\end{array}$} \\
\hline & & Acid Amount (mL/g) & $B /(A+B+C+D)$ & $(C+D) /(A+B+C+D)$ & $\mathrm{NO}_{x}$ & $\mathrm{NO}_{2}$ \\
\hline $\mathrm{SbZr}$ & 5.17 & 0.78 & 0.38 & 0.27 & 138.7 & 15.8 \\
\hline SbCeZr & 3.81 & 1.46 & 0.40 & 0.29 & 147.7 & 46.7 \\
\hline
\end{tabular}

${ }^{a}$ The amount of $\mathrm{H}_{2}$ consumption quantified by $\mathrm{CuO}$ as a calibration reference. ${ }^{\mathrm{b}}$ Acid amount and acid ratio calculated by $\mathrm{NH}_{3}$ desorption peak area in $\mathrm{NH}_{3}$-TPD. ${ }^{c} \mathrm{NO}_{x}$ adsorption capability calculated from NO-TPD.

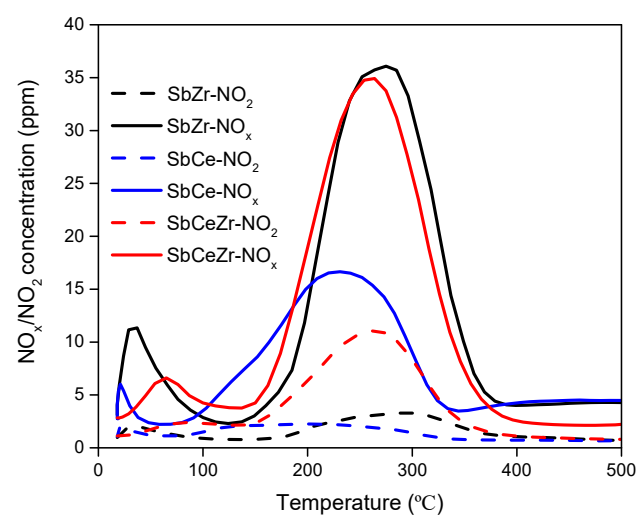

Figure 6. NO-TPD profiles of the catalysts.

$\mathrm{NO}_{2}$ came from the oxidation of adsorbed $\mathrm{NO}$ by active oxygen on the catalyst surface. The desorption temperature and peak area correlated with the adsorption strength and oxidation ability of $\mathrm{NO}$. The ability of the catalyst for oxidizing $\mathrm{NO}$ to $\mathrm{NO}_{2}$ plays an important role in improving the catalytic activities since it can promote the occurrence of the "fast SCR" reaction [42,43]. Considering the temperature range of the $\mathrm{NH}_{3}-\mathrm{SCR}$ reaction, the desorbed peaks in the temperature range of $150-400{ }^{\circ} \mathrm{C}$ were mainly discussed.

The main $\mathrm{NO}_{x}$ desorption peak of $\mathrm{SbCe}$ was at $245^{\circ} \mathrm{C}$, slightly lower than those of $\mathrm{SbCeZr}\left(258^{\circ} \mathrm{C}\right)$ and $\mathrm{SbZr}\left(273^{\circ} \mathrm{C}\right)$. The calculated $\mathrm{NO}_{x}$ amount was in the order of the following sequence: $\mathrm{SbCeZr}>$ $\mathrm{SbZr}>\mathrm{SbCe}$. There were no obvious differences in the $\mathrm{NO}_{x}$ desorption amount between $\mathrm{SbCeZr}$ and $\mathrm{SbZr}$, but the amount of $\mathrm{NO}_{x}$ desorption on $\mathrm{SbCeZr}$ was almost 2 times higher than that of SbCe. It is worth mentioning that $31.7 \% \mathrm{NO}$ converted to $\mathrm{NO}_{2}$ on $\mathrm{SbCeZr}$, while only $13.5 \% \mathrm{NO}$ did so on SbCe. With the help of $\mathrm{NO}_{2}$, the "fast $\mathrm{SCR}$ " occurred and facilitated $\mathrm{NO}_{x}$ removal. 


\subsection{5. $\mathrm{NH}_{3}-\mathrm{TPD}$}

Surface acidity of the catalysts plays a key role in the adsorption and activation of $\mathrm{NH}_{3}[44,45]$. $\mathrm{NH}_{3}$-TPD experiments were conducted to characterize the acid amount and strength according to peak area and desorption temperature, and the profiles are shown in Figure 7. Four broad peaks could be observed in the $\mathrm{NH}_{3}$-TPD profiles in the temperature range of $100-450{ }^{\circ} \mathrm{C}$. $\mathrm{NH}_{3}$ desorption peaks at low temperature $\left(<200{ }^{\circ} \mathrm{C}\right)$ were associated with $\mathrm{NH}_{3}$ desorption from weak acid sites derived from coordinatively unsaturated $\mathrm{Ce}^{\mathrm{n}+}$ or $\mathrm{Zr}^{\mathrm{n}+}$ sites [46,47], and the peaks in the temperature range of 200-300 ${ }^{\circ} \mathrm{C}$ were assigned to the dissociation of $\mathrm{NH}_{4}{ }^{+}$on Brønsted acid sites associated with surface hydroxyl groups. The peaks at temperatures higher than $300{ }^{\circ} \mathrm{C}$ were denoted as $\mathrm{NH}_{3}$ desorption from strong Lewis acid [48-50]. The original weak Lewis acidity of $\mathrm{CeO}_{2}$ and $\mathrm{ZrO}_{2}$ was also increased by $\mathrm{SbO}_{x}$ loading, which could be attributed to the electron withdrawing of $\mathrm{SbO}_{x}$ species in proximity of $\mathrm{Ce}^{\mathrm{n}+} / \mathrm{Zr}^{\mathrm{n}+}$ Lewis acid sites. The $\mathrm{NH}_{3}$ species desorbed from acid sites $\left(>200{ }^{\circ} \mathrm{C}\right)$ played a decisive role in the $\mathrm{NH}_{3}-\mathrm{SCR}$ reaction $[51,52]$.

The nature of the active sites could be assessed based on the quantity of sites and their intrinsic activity [49]. Quantitative analysis was employed to compare the amount of acid sites, and the ratios of different species based on the deconvoluted results are also shown in Table 2. The amount of acid sites had the following sequence: $\mathrm{SbCeZr}>\mathrm{SbCe}>\mathrm{SbZr}$. The large total acid amount was found over $\mathrm{SbCeZr}(1.46 \mathrm{~mL} / \mathrm{g})$, which was nearly 2 times as much as that on $\mathrm{SbZr}(0.78 \mathrm{~mL} / \mathrm{g})$. It suggested that the interaction among the catalyst components facilitated the increase in acid amount.

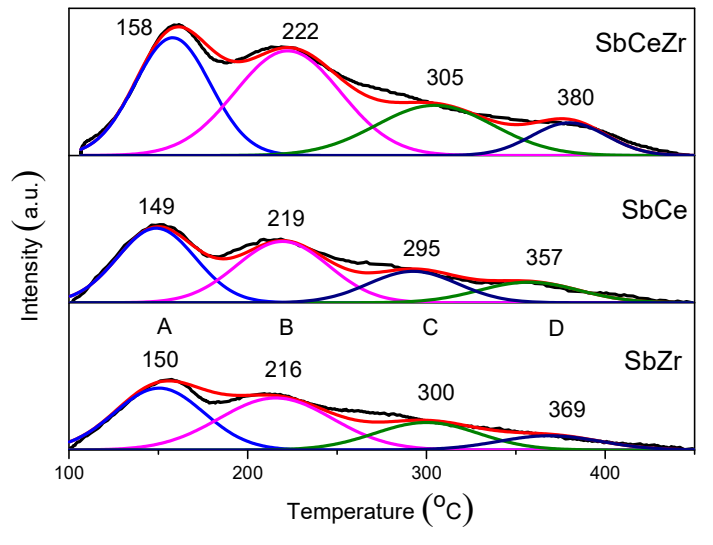

Figure 7. $\mathrm{NH}_{3}-\mathrm{TPD}$ profiles of the catalysts.

\subsection{In Situ DRIFT}

\subsubsection{Adsorption of $\mathrm{NH}_{3}$}

The adsorption and activation of $\mathrm{NH}_{3}$ play an important role in the $\mathrm{NH}_{3}-\mathrm{SCR}$ reaction [53]. The adsorption of $\mathrm{NH}_{3}$ was investigated by in situ DRIFT shown in Figure 8. The bands at 3166, 3241 , and $3357 \mathrm{~cm}^{-1}$ were assigned to $\mathrm{N}-\mathrm{H}$ stretching vibration modes of the coordinated $\mathrm{NH}_{3}[54,55]$. The bands at 1198 and $1599 \mathrm{~cm}^{-1}$ were attributed to coordinated $\mathrm{NH}_{3}$ linked to Lewis acid sites $\left(\mathrm{NH}_{3}-\mathrm{L}\right)[34,56]$, and the bands at 1440 and $1689 \mathrm{~cm}^{-1}$ were assigned to asymmetric and symmetric bending vibrations of $\mathrm{NH}_{4}{ }^{+}$bounded to Brønsted acid sites $\left(\mathrm{NH}_{4}{ }^{+}-\mathrm{B}\right)[15,40,50]$. The band at $1258 \mathrm{~cm}^{-1}$ was assigned to the deformation vibration of $\mathrm{NH}_{3}$ bonded to Lewis acid [57]. 


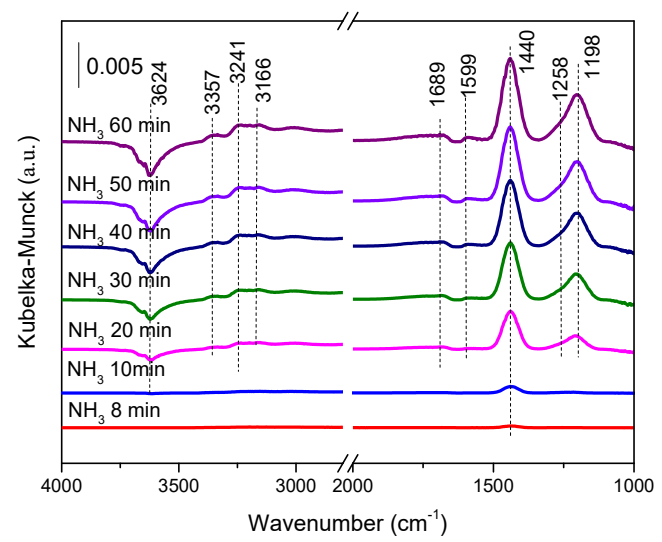

(a)

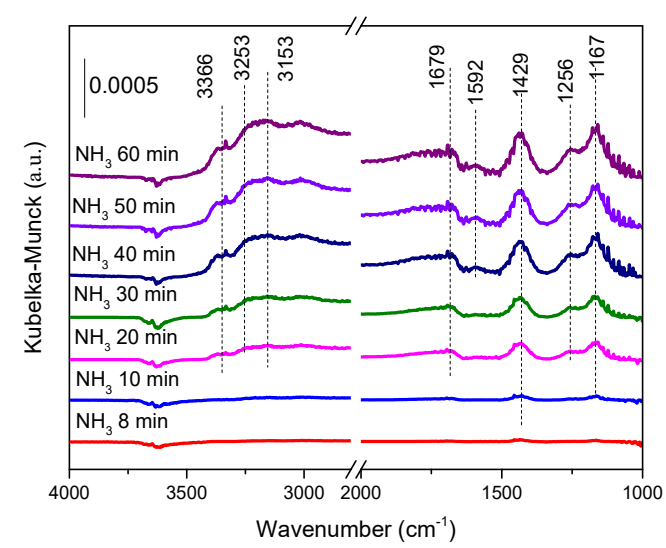

(b)

Figure 8. The in situ diffuse reflectance infrared Fourier transform (DRIFT) of $\mathrm{NH}_{3}$ adsorption over (a) the $\mathrm{SbCeZr}$ and (b) the SbCe catalysts at $200^{\circ} \mathrm{C}$.

$\mathrm{NH}_{4}{ }^{+}$-B species $\left(1440 \mathrm{~cm}^{-1}\right)$ appeared after exposing in $\mathrm{NH}_{3}$ for 8 min over $\mathrm{SbCeZr}$ as shown in Figure $8 \mathrm{a}$, and the adsorbed band turned intensive with the consumption of surface hydroxyl groups $\left(3624 \mathrm{~cm}^{-1}\right)$. However, the appearance of $\mathrm{NH}_{3}$-L species $\left(1198 \mathrm{~cm}^{-1}\right)$ lagged behind. Unlike SbCeZr, $\mathrm{NH}_{4}{ }^{+}$-B species $\left(1429,1679 \mathrm{~cm}^{-1}\right)$ and $\mathrm{NH}_{3}$ - L species $\left(1167,1256 \mathrm{~cm}^{-1}\right)$ were observed synchronously over SbCe (Figure 8b). Compared with $\mathrm{SbCe}$, an obvious blue shift of $\mathrm{NH}_{3}$ adsorption on acid sites was found over $\mathrm{SbCeZr}$, presenting the strong $\mathrm{NH}_{3}$ adsorption on SbCeZr. After exposure in $\mathrm{NH}_{3}$ for $60 \mathrm{~min}$, the difference in the distribution of $\mathrm{NH}_{4}{ }^{+}-\mathrm{B}$ and $\mathrm{NH}_{3}$ - $\mathrm{L}$ species was found. It should be recalled that a great discrepancy was noticed for the bands of $\mathrm{NH}_{4}{ }^{+}-\mathrm{B}$ and $\mathrm{NH}_{3}$ - $\mathrm{L}$ species in two samples. By calculating the band intensity of $\mathrm{NH}_{3}$ adsorption, a high proportion of $\mathrm{NH}_{4}{ }^{+}$-B species was found on $\mathrm{SbCeZr}$, while the proportions of $\mathrm{NH}_{4}{ }^{+}-\mathrm{B}$ and $\mathrm{NH}_{3}-\mathrm{L}$ species on $\mathrm{SbCe}$ were similar. The presence of abundant Brønsted and Lewis acid sites on the SbCeZr catalyst should be responsible for the improvement in SCR activities over a wide temperature range [58].

\subsubsection{Adsorption of $\mathrm{NH}_{3}$ Followed by Introduction of $\mathrm{NO}+\mathrm{O}_{2}$}

The spectra of introducing $\mathrm{NO}+\mathrm{O}_{2}$ into the catalysts after $\mathrm{NH}_{3}$ adsorption as a function of time were recorded and are shown in Figure 9. The decrease of $\mathrm{NH}_{4}{ }^{+}-\mathrm{B}$ and $\mathrm{NH}_{3}-\mathrm{L}$ species on SbCeZr with the introduction of $\mathrm{NO}+\mathrm{O}_{2}$ presented the reaction between $\mathrm{NO}_{x}$ and adsorbed $\mathrm{NH}_{3}$ species (Figure 9a). The intensities of the bands ascribed to $\mathrm{NH}_{3}-\mathrm{L}$ and $\mathrm{NH}_{4}{ }^{+}$-B species were reduced after $\mathrm{NH}_{3}$ adsorption, showing that these surface species were able to react with the mixture of $\mathrm{NO}$ and $\mathrm{O}_{2}$ at $200{ }^{\circ} \mathrm{C}$. A deeper insight into the reduction of band intensity with the reaction time over the catalysts was essential. The further investigation on the consumption rate of $\mathrm{NH}_{3}-\mathrm{L}$ and $\mathrm{NH}_{4}{ }^{+}-\mathrm{B}$ species showed the slightly faster disappearance of $\mathrm{NH}_{3}$ - $\mathrm{L}$ species than $\mathrm{NH}_{4}{ }^{+}$-B species in the reaction. Extending the exposure time led to the appearance of nitrate species, such as bridged nitrate $\left(1605\right.$ and $\left.1247 \mathrm{~cm}^{-1}\right)$ [59], bidentate nitrate $\left(1579,1559\right.$, and $\left.1516 \mathrm{~cm}^{-1}\right)$ [55], and monodentate nitrate $\left(1541 \mathrm{~cm}^{-1}\right)$ [60]. The recovery of the negative broad band of surface hydroxyl groups $\left(3441 \mathrm{~cm}^{-1}\right)$ was attributed to the formation of water, which further confirmed the occurrence of the reaction. 


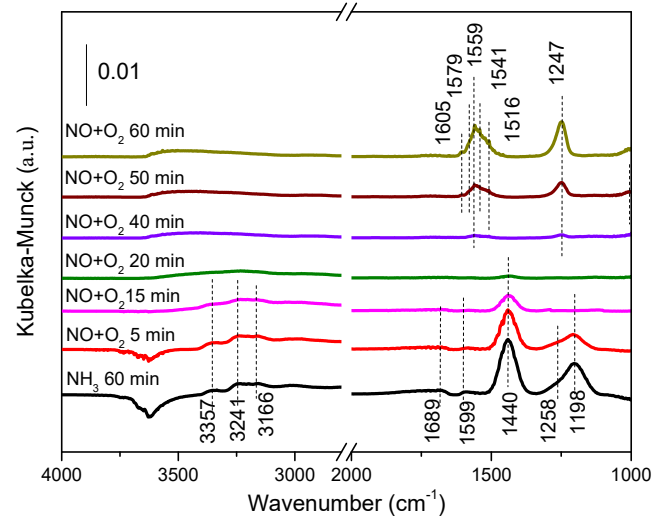

(a)

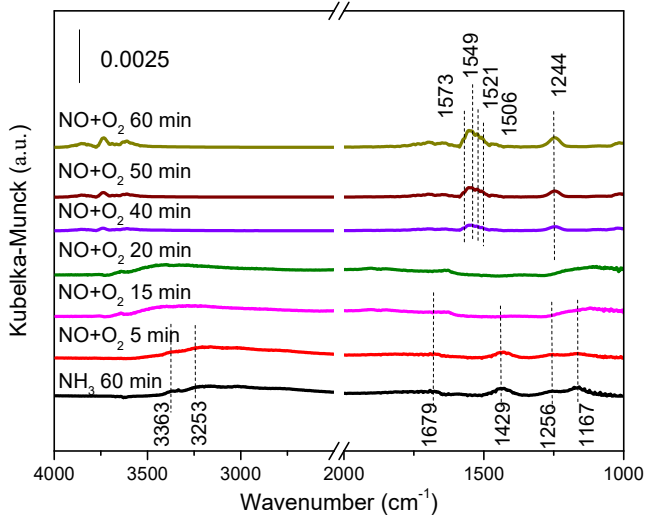

(b)

Figure 9. The in situ DRIFT of $\mathrm{NO}+\mathrm{O}_{2}$ reacting with preadsorbed $\mathrm{NH}_{3}$ species over (a) the $\mathrm{SbCeZr}$ and (b) the SbCe catalysts at $200^{\circ} \mathrm{C}$.

As shown in Figure 9b, the phenomenon that occurred on SbCe was similar to that on $\mathrm{SbCeZr}$, i.e., the appearance of nitrate species at the expense of the disappearance of adsorbed $\mathrm{NH}_{3}$. The disappearance of $\mathrm{NH}_{3}-\mathrm{L}$ species confirmed that $\mathrm{NH}_{3}-\mathrm{L}$ species could be involved in the reaction, and $\mathrm{NH}_{3}-\mathrm{L}$ species were slightly active compared with $\mathrm{NH}_{4}{ }^{+}-\mathrm{B}$ species. The adsorbed $\mathrm{NH}_{3}$ on the catalyst surface reacted with $\mathrm{NO} / \mathrm{NO}_{2}$ in the gas phase, following the Eley-Rideal (E-R) mechanism.

\subsubsection{Co-Adsorption of $\mathrm{NO}+\mathrm{O}_{2}$}

The adsorption of $\mathrm{NO}+\mathrm{O}_{2}$ was investigated by in situ DRIFT. As shown in Figure 10a, bridged nitrate $\left(1245,1606 \mathrm{~cm}^{-1}\right)$, bidentate nitrate $\left(1579,1559,1519 \mathrm{~cm}^{-1}\right)$, and monodentate nitrate $\left(1539 \mathrm{~cm}^{-1}\right)$ were formed on $\mathrm{SbCeZr}$ after exposure to $\mathrm{NO}+\mathrm{O}_{2}$ for $30 \mathrm{~min}$. The $\mathrm{NH}_{3}$ adsorption rate was much faster than the $\mathrm{NO}_{x}{ }^{-}$generation rate. With the exposure time prolonged, the bands of nitrate intensified accordingly. Bridged nitrate seemed dominant in all the kinds of nitrates. In the case of SbCe (Figure 10b), rather weak bands of nitrates were observed after the exposure to the same feed gas for the same time, and the adsorption intensity of bridged nitrate was rather weaker than that of the monodentate and bidentate nitrates. It could be seen that $\mathrm{Sb}$ interacted with different metals (Ce or $\mathrm{CeZr}$ ), resulting in the difference in the $\mathrm{NO}_{3}{ }^{-}$species distribution on the catalyst surface.

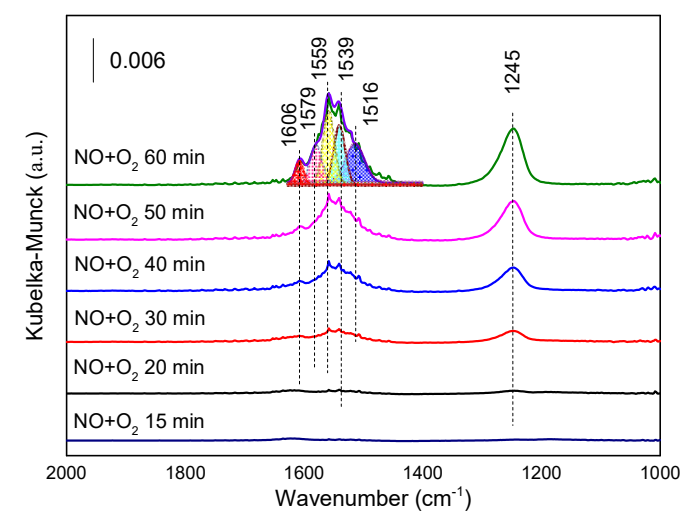

(a)

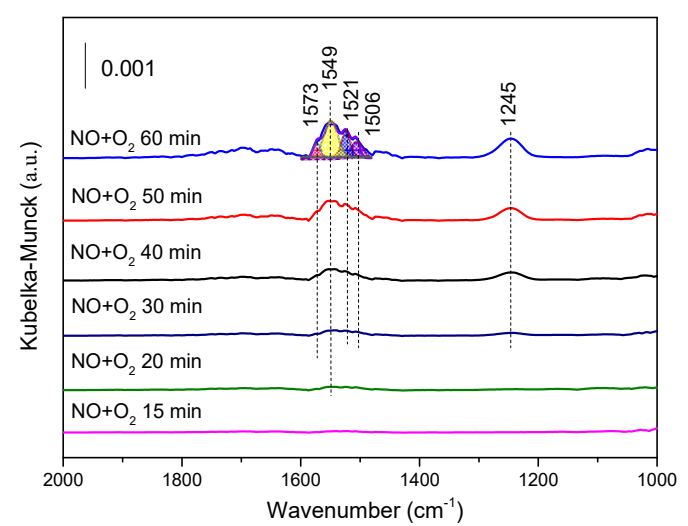

(b)

Figure 10. The in situ DRIFT of $\mathrm{NO}+\mathrm{O}_{2}$ co-adsorption over (a) the SbCeZr and (b) the SbCe catalysts at $200{ }^{\circ} \mathrm{C}$. 


\subsubsection{Adsorption of $\mathrm{NO}+\mathrm{O}_{2}$ Followed by Introduction of $\mathrm{NH}_{3}$}

Compared with the results of $\mathrm{NO}+\mathrm{O}_{2}$ reacting with preadsorbed $\mathrm{NH}_{3}$ (Figure 9), the effects of adding $\mathrm{NH}_{3}$ to preadsorbed $\mathrm{NO}+\mathrm{O}_{2}$ (Figure 11) on activity were not so obvious. It is worth mentioning that a new band linked to $\mathrm{NH}_{4}{ }^{+}-\mathrm{B}$ species $\left(1440 \mathrm{~cm}^{-1}\right)$ gradually formed over $\mathrm{SbCeZr}$ as the exposure time increased. However, the bands linked to $\mathrm{NH}_{3}-\mathrm{L}\left(1599\right.$ and $1198 \mathrm{~cm}^{-1}$ ) were not detected. Therefore, the formed nitrate species had detrimental effects on $\mathrm{NH}_{3}$ adsorption on Lewis sites, but negligent effects on $\mathrm{NH}_{3}$ adsorption on Brønsted acid sites.

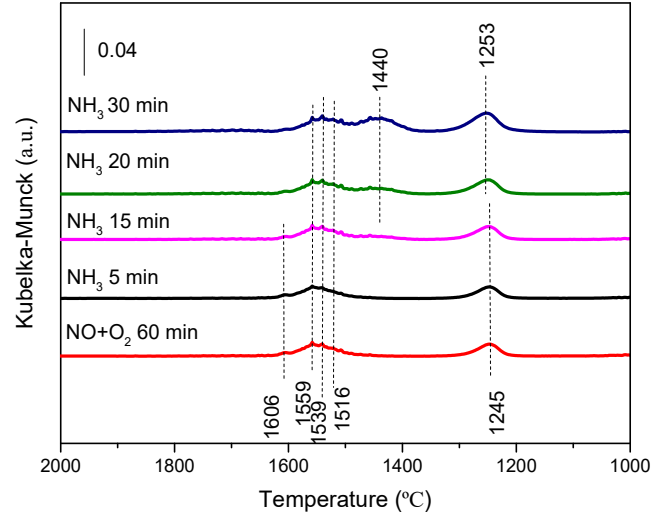

(a)

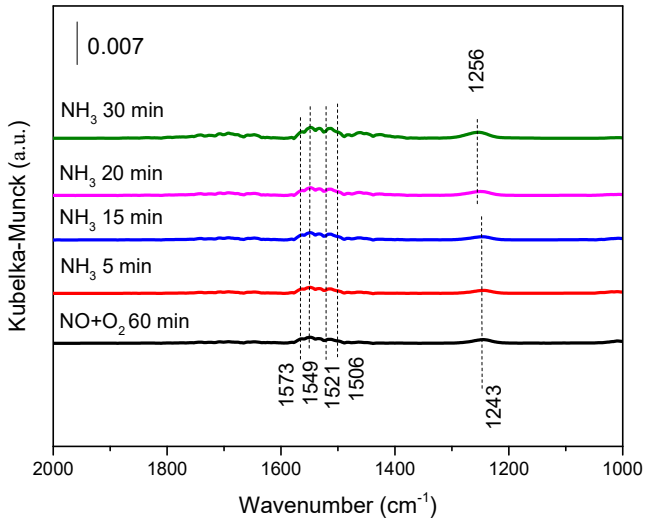

(b)

Figure 11. The in situ DRIFT of $\mathrm{NH}_{3}$ reacting with preadsorbed $\mathrm{NO}+\mathrm{O}_{2}$ over (a) the $\mathrm{SbCeZr}$ and (b) the SbCe catalysts at $200{ }^{\circ} \mathrm{C}$.

On the contrary, there were no bands related to $\mathrm{NH}_{3}$ adsorption over SbCe even after prolonging the exposure time up to $30 \mathrm{~min}$. The phenomena illustrated that the formed nitrate species significantly inhibited $\mathrm{NH}_{3}$ adsorption. Combined with the results of Figure 11, this indicated that $\mathrm{NH}_{3}$ adsorption and $\mathrm{NO}_{x}$ oxidation could be competitive on $\mathrm{SbCe}$, but not on $\mathrm{SbCeZr}$.

\subsection{Discussion}

$\mathrm{NO}_{x}$ conversions over $\mathrm{CeO}_{2}$ and $\mathrm{SbO}_{x}$ were very low, but it increased significantly when they were combined together. Compared with $\mathrm{CeO}_{2}$, the reason for the improvement of catalytic activity over $\mathrm{SbCeO}_{x}$ was due to alleviating nitrate adsorption and leaving more active sites for $\mathrm{NH}_{3}$ adsorption and activation [40]. Considering the competitive adsorption between $\mathrm{NH}_{3}$ and nitrate species, we prepared $\mathrm{SbCeZr}$ and investigated it for $\mathrm{NH}_{3}-\mathrm{SCR}$ performance. SbCeZr outperformed SbCe not only in activity and stability but also in $\mathrm{SO}_{2}$ and water tolerance. $\mathrm{SbCeZr}$ exhibited high activity with $\mathrm{NO}_{x}$ conversion over $80 \%$ in the temperature range of $202-422{ }^{\circ} \mathrm{C}$. The introduction of $\mathrm{H}_{2} \mathrm{O}$ and $\mathrm{SO}_{2}$ had little influence on the activity of $\mathrm{SbCeZr}$, but an adverse effect on the catalytic activity of $\mathrm{SbCe}$ was found.

The presence of $\mathrm{Zr}$ influenced the distribution of $\mathrm{Sb}$ on the surface or bulk. According to ICP-AES and XPS results (Table 1), the surface amount of $\mathrm{Sb}$ on $\mathrm{SbCe}$ was much higher than that on $\mathrm{SbCeZr}$, displaying the enrichment of $\mathrm{Sb}$ on the $\mathrm{SbCe}$ surface. However, $\mathrm{H}_{2}-\mathrm{TPR}$ indicated the strong interaction between $\mathrm{SbO}_{x}$ and $\mathrm{CeO}_{2}$. Unlike $\mathrm{SbCe}$, the presence of $\mathrm{Zr}$ made the distribution of $\mathrm{Sb}, \mathrm{Ce}$, and $\mathrm{Zr}$ uniform and weakened the interaction between $\mathrm{SbO}_{x}$ and $\mathrm{CeO}_{2}$. The weakened interaction also brought about abundant $\mathrm{Sb}^{5+}$ species on the catalyst surface (Table 1) and the lower onset reduction temperature of active oxygen (Figure 5). Furthermore, the generation of $\mathrm{NO}_{2}$ during NO-TPD (Figure 6) also illustrated the enhancement in reducibility, which facilitated the "fast SCR" reaction during $\mathrm{NH}_{3}$-SCR [32].

The adsorption of $\mathrm{NH}_{3}$ on the catalyst surface was considered as the initial step of the $\mathrm{NH}_{3}$-SCR reaction [15], so $\mathrm{NH}_{3}$ adsorption played an important role during $\mathrm{NO}_{x}$ removal. Compared with SbCe, $\mathrm{NH}_{3}$ adsorption was enhanced on $\mathrm{SbCeZr}$, which was attributed to the increase of Brønsted and Lewis 
acid amounts (Figure 7). The acid distribution on the catalysts was different. The amount of Brønsted acid was higher than the amount of Lewis acid on SbCeZr, whereas the amount of Brønsted acid was similar to that of Lewis acid on SbCe. Meanwhile, in situ DRIFT experiments of $\mathrm{NH}_{3}$ adsorption also confirmed the strong adsorption of $\mathrm{NH}_{3}$ and the faster adsorption rate on $\mathrm{SbCeZr}$ (Figure 8). The reaction rate of $\mathrm{NO}_{x}$ with $\mathrm{NH}_{3}$ adsorbed on Lewis acid was slightly faster than that with $\mathrm{NH}_{4}{ }^{+}$ adsorbed on Brønsted acid (Figure 9) (E-R mechanism).

It is worth mentioning that the formed nitrates had negligible effects on the adsorption of $\mathrm{NH}_{3}$ over SbCeZr; however, detrimental impacts were found over SbCe. It meant that NO oxidation and $\mathrm{NH}_{3}$ adsorption were both around $\mathrm{Ce}^{\mathrm{n}+}$ sites, so there was competition between them. Amorphous $\mathrm{ZrO}_{2}$ possessed abundant hydroxyl [61], which showed obvious acidity properties. Then, the strong withdrawing effects of $\mathrm{SbO}_{x}$ further increased the acid amount and strength of $\mathrm{ZrO}_{2}$, which was confirmed by the high $\mathrm{NH}_{3}$ desorption amount (Figure 7). Therefore, the separation of active sites alleviated the competition effects between $\mathrm{NO}$ oxidation and $\mathrm{NH}_{3}$ adsorption, thus promoting $\mathrm{NO}_{x}$ removal.

Given the above discussion, it was shown that the strong acid and weak reducibility of SbZr made it less active in $\mathrm{NH}_{3}-\mathrm{SCR}$. However, a strengthened interaction was found between $\mathrm{SbO}_{x}$ and $\mathrm{CeO}_{2}$, favoring $\mathrm{NO}_{x}$ removal. Unfortunately, the competition between $\mathrm{NO}$ oxidation and $\mathrm{NH}_{3}$ adsorption on the same active sites still needed to be alleviated to improve its thermostability and activity in the presence of $\mathrm{H}_{2} \mathrm{O}$ and $\mathrm{SO}_{2}$. In the presence of $\mathrm{ZrO}_{2}, \mathrm{NH}_{3}$ adsorption and $\mathrm{NO}$ oxidation on different active sites widened the operation window.

\section{Materials and Methods}

\subsection{Catalyst Preparation}

The SbCe, SbCeZr, and SbZr catalysts, where the molar ratio of $\mathrm{Sb} / \mathrm{Ce}$ and $\mathrm{Zr} / \mathrm{Ce}$ was 1.0, were prepared by the citric acid method. First, $\mathrm{Sb}\left(\mathrm{CH}_{3} \mathrm{COO}\right)_{3}$ was dissolved in a solution of citric acid, then $\mathrm{Zr}\left(\mathrm{NO}_{3}\right)_{4}$ and $\mathrm{Ce}\left(\mathrm{NO}_{3}\right)_{4}$ were added. The molar ratio of citric acid to total metal components (the sum of $\mathrm{Ce}, \mathrm{Zr}$, and $\mathrm{Sb}$ ) was 1.5 . Then, the resultant mixture was stirred at $80^{\circ} \mathrm{C}$ in a water bath until forming a gel. The gel was dried at $110^{\circ} \mathrm{C}$ for $12 \mathrm{~h}$ to form a porous, foamlike solid. Finally, the precursor was calcined at $500{ }^{\circ} \mathrm{C}$ for $3 \mathrm{~h}$ in a muffle furnace (SX2, Shanghai Pudong Rong-Feng Scientific Instrument Co. Ltd., Shanghai, China). After calcining, the sample was crushed and sieved to $40-60$ mesh prior to evaluation. $\mathrm{CeO}_{2}, \mathrm{SbO}_{x}$, and $\mathrm{ZrO}_{2}$ were also prepared by the same method.

\subsection{Catalytic Activity Testing}

The catalytic activities of the catalysts for the selective catalytic reduction of $\mathrm{NO}_{x}$ with $\mathrm{NH}_{3}$ in excess oxygen were conducted at atmospheric pressure in a fixed-bed continuous flow quartz reactor. In the evaluation, a $200 \mathrm{mg}$ portion of catalyst (40-60 mesh) was applied, and the feed gas contained $500 \mathrm{ppm} \mathrm{NO}, 500 \mathrm{ppm} \mathrm{NH}_{3}, 5 \% \mathrm{O}_{2}, 5 \% \mathrm{H}_{2} \mathrm{O}$ (when used), $100 \mathrm{ppm} \mathrm{SO}_{2}$ (when used), and Ar balance. The total flow was $300 \mathrm{~mL} / \mathrm{min}$ and the gas hourly space velocity (GHSV) was about 150,000 $\mathrm{h}^{-1}$. A Thermo Fisher NO-NO ${ }_{x}$-chemiluminescence analyzer (Waltham, MA, USA) was used to detect the concentration of $\mathrm{NO}$ and $\mathrm{NO}_{2}$ before and after the reaction. The catalyst bed was heated at $2{ }^{\circ} \mathrm{C} / \mathrm{min}$, held for 45 min every $50^{\circ} \mathrm{C}$, and then the concentration of $\mathrm{NO}_{x}$ was measured. $\mathrm{NO}_{x}$ conversion was calculated using the following equation:

$$
\mathrm{NO}_{x} \text { conversion }=\frac{\left[\mathrm{NO}_{x}\right]_{\text {in }}-\left[\mathrm{NO}_{x}\right]_{\text {out }}}{\left[\mathrm{NO}_{x}\right]_{\text {in }}} \times 100 \%
$$

where $\left[\mathrm{NO}_{x}\right]_{\text {in }}$ and $\left[\mathrm{NO}_{x}\right]_{\text {out }}$ represented the inlet and outlet concentrations of $\mathrm{NO}_{x}$, respectively. 


\subsection{Catalyst Characterization}

The $\mathrm{N}_{2}$ adsorption-desorption isotherms were measured on a Quantachrome NOVA1200 analyzer (Norcross, GA, USA) at $-196{ }^{\circ} \mathrm{C}$ to obtain the surface area of the catalysts. Before measurement, the catalyst was degassed at $180{ }^{\circ} \mathrm{C}$ until it reached a stable vacuum of approximately 5 mTorr. After calculating the desorption data using the Brunauer-Emmett-Teller (BET) method, the specific surface area was obtained. The X-ray diffraction (XRD) patterns were carried out on a Bruker/D8 diffractometer (Karlsruhe, Germany) with $\mathrm{Cu} K \alpha$ radiation $(\lambda=0.154 \mathrm{~nm})$. The X-ray photoelectron spectroscopy (XPS) spectra were obtained using a Thermo Scientific ESCALAB 250 spectrometer analyzer (Waltham, MA, USA), using a monochromatized Al-K $\alpha$ source $(1486.6 \mathrm{eV})$, and the binding energy of adventitious carbon $(284.6 \mathrm{eV})$ was taken as a reference.

The temperature-programmed reduction of $\mathrm{H}_{2}\left(\mathrm{H}_{2}-\mathrm{TPR}\right)$ and the temperature-programmed desorption of $\mathrm{NH}_{3}\left(\mathrm{NH}_{3}-\mathrm{TPD}\right)$ were performed on a PX200 apparatus (Tianjin Pengxiang Technology Co. Ltd., Tianjin, China) with a thermal conductivity detector (TCD). For the $\mathrm{H}_{2}$-TPR experiment, a $100 \mathrm{mg}$ portion of catalyst was pretreated in $\mathrm{N}_{2}$ at $300{ }^{\circ} \mathrm{C}$ for $30 \mathrm{~min}$, then cooled down to $30^{\circ} \mathrm{C}$. Finally, the catalyst was heated from $30^{\circ} \mathrm{C}$ to $800{ }^{\circ} \mathrm{C}$ at a rate of $10{ }^{\circ} \mathrm{C} / \mathrm{min}$ in $5 \% \mathrm{H}_{2} / \mathrm{Ar}(40 \mathrm{~mL} / \mathrm{min})$. For the $\mathrm{NH}_{3}$-TPD, a $100 \mathrm{mg}$ portion of catalyst was pretreated at $500^{\circ} \mathrm{C}$ under a flow of $\mathrm{Ar}(50 \mathrm{~mL} / \mathrm{min})$ for $1 \mathrm{~h}$, and the pretreated catalyst was exposed to a flow of $10 \% \mathrm{NH}_{3} / \mathrm{Ar}(40 \mathrm{~mL} / \mathrm{min})$ for $1 \mathrm{~h} \mathrm{at} 100^{\circ} \mathrm{C}$. Then, the sample was flushed by $\operatorname{Ar}(50 \mathrm{~mL} / \mathrm{min})$ for $1 \mathrm{~h}$ and heated from $100{ }^{\circ} \mathrm{C}$ to $500^{\circ} \mathrm{C}$ at $10^{\circ} \mathrm{C} / \mathrm{min}$.

The temperature-programmed desorption of NO (NO-TPD) experiments were conducted on custom-made equipment with a $\mathrm{NO}_{x}$ analyzer. Before testing, a $200 \mathrm{mg}$ portion of catalyst was pretreated at $500^{\circ} \mathrm{C}$ under a flow of $\operatorname{Ar}(300 \mathrm{~mL} / \mathrm{min})$ for $1 \mathrm{~h}$; after cooling to room temperature, the pretreated catalyst adsorbed NO with a flow of $500 \mathrm{ppm} \mathrm{NO} / \mathrm{Ar}(300 \mathrm{~mL} / \mathrm{min})$ for $1 \mathrm{~h}$. The catalyst was flushed by $\operatorname{Ar}(300 \mathrm{~mL} / \mathrm{min})$ for $1 \mathrm{~h}$ and then heated from room temperature to $500{ }^{\circ} \mathrm{C}$ at $10^{\circ} \mathrm{C} / \mathrm{min}$.

In situ DRIFT spectra were collected using an FTIR spectrometer (Thermo Nicolet 6700, Waltham, MA, USA) with an MCT detector cooled by liquid nitrogen. Before each experiment, the catalyst was pretreated at $300{ }^{\circ} \mathrm{C}$ for $1 \mathrm{~h}$ in $\mathrm{Ar}(50 \mathrm{~mL} / \mathrm{min})$. After the temperature cooling to $200^{\circ} \mathrm{C}, 1000 \mathrm{ppm}$ $\mathrm{NH}_{3} / \mathrm{Ar}$ was introduced into the IR cell and the background was subtracted from the sample spectra. After adsorption saturation, $1000 \mathrm{ppm} \mathrm{NO}+5 \% \mathrm{O}_{2} / \mathrm{Ar}$ was introduced to replace $\mathrm{NH}_{3}$ at $200{ }^{\circ} \mathrm{C}$. The experiment of $\mathrm{NO}+\mathrm{O}_{2}$ adsorption and reaction with $\mathrm{NH}_{3}$ was carried out following a similar process. First, the catalyst was pretreated at $300^{\circ} \mathrm{C}$ for $1 \mathrm{~h}$ in $\operatorname{Ar}(50 \mathrm{~mL} / \mathrm{min})$, then $1000 \mathrm{ppm} \mathrm{NO}+5 \%$ $\mathrm{O}_{2} / \mathrm{Ar}$ adsorption was carried out at $200{ }^{\circ} \mathrm{C}$, and finally $1000 \mathrm{ppm} \mathrm{NH} / \mathrm{Ar}$ was introduced to replace $\mathrm{NO}+\mathrm{O}_{2}$.

\section{Conclusions}

Sb-containing metal oxides (SbZr, SbCe, SbCeZr) were prepared by citric acid method and investigated for $\mathrm{NH}_{3}-\mathrm{SCR}$. SbCeZr exhibited the higher performance in $\mathrm{NH}_{3}-\mathrm{SCR}$ than $\mathrm{SbCe}$ and $\mathrm{SbZr}$, and $\mathrm{NO}_{x}$ could be removed with $80 \%$ conversion in the temperature range of $202-422{ }^{\circ} \mathrm{C}$. SbCeZr owned excellent activity even in the presence of water and $\mathrm{SO}_{2}$, and the thermostability was improved compared with $\mathrm{SbCe}$. Hence, $\mathrm{SbCeZr}$ seemed to be a good candidate for the practical application in $\mathrm{deNO}_{x}$. The presence of $\mathrm{Sb}$ in the metal oxides led to the difference in acid distribution and redox property, which was closely related to the $\mathrm{NH}_{3}$ adsorption and $\mathrm{NO}$ oxidation. Brønsted acid and Lewis acid distributed evenly on SbCe, while Brønsted acid dominated on SbCeZr. Although high amounts of acid were on $\mathrm{SbZr}$, poor redox led to its negligent performance in $\mathrm{NH}_{3}-\mathrm{SCR}$. The enhancement in redox ability promoted the generation of nitrates on SbCe. However, the competition between NO oxidation and $\mathrm{NH}_{3}$ adsorption on the same active sites limited its application. In the presence of $\mathrm{ZrO}_{2}$, the interaction between $\mathrm{Sb}$ and $\mathrm{Ce}$ was weakened, which further increased the acid amount and redox property. The form of "dual active sites" favored the $\mathrm{NH}_{3}$ adsorption and nitrate generation. 
Author Contributions: Conceptualization, Q.X. and L.W.; methodology, Q.X., D.L. and C.W.; validation, L.W. and Y.G. (Yun Guo); formal analysis, Q.X., L.W., Q.K. and M.N.H.; investigation, D.L., Q.K. and M.N.H.; resources, W.Z., Y.G. (Yun Guo) and Y.G. (Yanglong Guo); data curation, Q.X., Q.K. and L.W.; writing-original draft preparation, Q.X. and L.W.; writing-review and editing, Q.X., L.W. and W.Z.; project administration, Y.G. (Yanglong Guo); funding acquisition, Y.G. (Yun Guo) and Y.G. (Yanglong Guo). All authors have read and agreed to the published version of the manuscript.

Funding: This project was supported financially by the National Key Research and Development Program of China (2016YFC0204300) and the National Natural Science Foundation of China (21976057 and 21922602), as well as the "Shanghai Science and Technology Innovation Plan" Program (19DZ1208000), and Fundamental Research Funds for the Central Universities.

Conflicts of Interest: The authors declare no conflict of interest.

\section{References}

1. Irfan, M.F.; Goo, J.H.; Kim, S.D. $\mathrm{Co}_{3} \mathrm{O}_{4}$ based catalysts for $\mathrm{NO}$ oxidation and NOx reduction in fast SCR process. Appl. Catal. B Environ. 2008, 78, 267-274. [CrossRef]

2. Fu, M.; Li, C.; Lu, P.; Qu, L.; Zhang, M.; Zhou, Y.; Yu, M.; Fang, Y. A review on selective catalytic reduction of NOx by supported catalysts at $100-300{ }^{\circ} \mathrm{C}$-Catalysts, mechanism, kinetics. Catal. Sci. Technol. 2014, 4, 14-25. [CrossRef]

3. Xu, Q.; Fang, Z.L.; Chen, Y.Y.; Guo, Y.L.; Guo, Y.; Wang, L.; Wang, Y.S.; Zhang, J.S.; Zhan, W.C. Titania-Samarium-Manganese Composite Oxide for the Low-Temperature Selective Catalytic Reduction of $\mathrm{NO}$ with $\mathrm{NH}_{3}$. Environ. Sci. Technol. 2020, 54, 2530-2538. [CrossRef]

4. Zhan, W.C.; Guo, Y.; Gong, X.Q.; Guo, Y.L.; Wang, Y.Q.; Lu, G.Z. Current status and perspectives of rare earth catalytic materials and catalysis. Chin. J. Catal. 2014, 35, 1238-1250. [CrossRef]

5. Peng, Y.; Wang, D.; Li, B.; Wang, C.; Li, J.; Crittenden, J.; Hao, J. Impacts of Pb and $\mathrm{SO}_{2}$ Poisoning on $\mathrm{CeO}_{2}-\mathrm{WO}_{3} / \mathrm{TiO}_{2}-\mathrm{SiO}_{2} \mathrm{SCR}$ Catalyst. Environ. Sci. Technol. 2017, 51, 11943-11949. [CrossRef]

6. $\mathrm{Xu}, \mathrm{T}$; $\mathrm{Wu}, \mathrm{X}$; Gao, Y.; Lin, Q.; Hu, J.; Wang, D. Comparative study on sulfur poisoning of $\mathrm{V}_{2} \mathrm{O}_{5}-\mathrm{Sb}_{2} \mathrm{O}_{3} / \mathrm{TiO}_{2}$ and $\mathrm{V}_{2} \mathrm{O}_{5}-\mathrm{WO}_{3} / \mathrm{TiO}_{2}$ monolithic catalysts for low-temperature $\mathrm{NH}_{3}$-SCR. Catal. Commun. 2017, 93, 33-36. [CrossRef]

7. Kwon, D.W.; Hong, S.C. Enhancement of performance and sulfur resistance of ceria-doped V/Sb/Ti by sulfation for selective catalytic reduction of NOx with ammonia. RSC Adv. 2016, 6, 1169-1181. [CrossRef]

8. Xu, L.; Wang, C.; Chang, H.; Wu, Q.; Zhang, T.; Li, J. New Insight into $\mathrm{SO}_{2}$ Poisoning and Regeneration of $\mathrm{CeO}_{2}-\mathrm{WO}_{3} / \mathrm{TiO}_{2}$ and $\mathrm{V}_{2} \mathrm{O}_{5}-\mathrm{WO}_{3} / \mathrm{TiO}_{2}$ Catalysts for Low-Temperature $\mathrm{NH}_{3}-\mathrm{SCR}$. Environ. Sci. Technol. 2018, 52, 7064-7071. [CrossRef]

9. Zhang, H.; Sun, K.; Feng, Z.; Ying, P.; Li, C. Studies on the SbOx species of $\mathrm{SbOx} / \mathrm{SiO}_{2}$ catalysts for methane-selective oxidation to formaldehyde. Appl. Catal. A Gen. 2006, 305, 110-119. [CrossRef]

10. Qu, R.; Gao, X.; Cen, K.; Li, J. Relationship between structure and performance of a novel cerium-niobium binary oxide catalyst for selective catalytic reduction of $\mathrm{NO}$ with $\mathrm{NH}_{3}$. Appl. Catal. B Environ. 2013, 142, 290-297. [CrossRef]

11. Topsøe, N.Y. Mechanism of the selective catalytic reduction of nitric oxide by ammonia elucidated by in situ on-line Fourier transform infrared spectroscopy. Science 1994, 265, 1217-1219. [CrossRef] [PubMed]

12. Zhang, T.; Qu, R.; Su, W.; Li, J. A novel Ce-Ta mixed oxide catalyst for the selective catalytic reduction of NOx with $\mathrm{NH}_{3}$. Appl. Catal. B Environ. 2015, 176, 338-346. [CrossRef]

13. Guo, R.; Sun, X.; Liu, J.; Pan, W.; Li, M.; Sun, P.; Liu, S. Enhancement of the $\mathrm{NH}_{3}-\mathrm{SCR}$ catalytic activity of $\mathrm{MnTiO}_{\mathrm{x}}$ catalyst by the introduction of Sb. Appl. Catal. A Gen. 2018, 558, 1-8. [CrossRef]

14. Shi, R.H.; Lin, X.Y.; Zheng, Z.G.; Feng, R.; Liu, Y.M.; Ni, L.F.; Yuan, B.H. Selective catalytic reduction of NOx with $\mathrm{NH}_{3}$ over $\mathrm{Sb}$ modified CeZrOx catalyst. React. Kinet. Mech. Cat. 2018, 124, 217-227. [CrossRef]

15. Liu, J.; Li, G.; Zhang, Y.; Liu, X.; Wang, Y.; Li, Y. Novel Ce-W-Sb mixed oxide catalyst for selective catalytic reduction of $\mathrm{NOx}$ with $\mathrm{NH}_{3}$. Appl. Surf. Sci. 2017, 401,7-16. [CrossRef]

16. Danh, H.T.; Kumar, P.A.; Jeong, Y.E.; Ha, H.P. Enhanced $\mathrm{NH}_{3}-\mathrm{SCR}$ activity of $\mathrm{Sb}-\mathrm{V} / \mathrm{CeO}_{2}-\mathrm{TiO}_{2}$ catalyst at low temperatures by synthesis modification. Res. Chem. Intermed. 2016, 42, 155-169. [CrossRef]

17. Du, X.; Gao, X.; Fu, Y.; Gao, F.; Luo, Z.; Cen, K. The co-effect of Sb and Nb on the SCR performance of the $\mathrm{V}_{2} \mathrm{O}_{5} / \mathrm{TiO}_{2}$ catalyst. J. Colloid Interface Sci. 2012, 368, 406-412. [CrossRef] 
18. Phil, H.H.; Reddy, M.P.; Kumar, P.A.; Ju, L.K.; Hyo, J.S. $\mathrm{SO}_{2}$ resistant antimony promoted $\mathrm{V}_{2} \mathrm{O}_{5} / \mathrm{TiO}_{2}$ catalyst for $\mathrm{NH}_{3}$-SCR of NOx at low temperatures. Appl. Catal. B Environ. 2008, 78, 301-308. [CrossRef]

19. Kim, J.; Lee, S.; Kwon, D.W.; Lee, K.Y.; Ha, H.P. $\mathrm{SO}_{3}{ }^{2-} / \mathrm{SO}_{4}{ }^{2-}$ functionalization-tailorable catalytic surface features of Sb-promoted $\mathrm{Cu}_{3} \mathrm{~V}_{2} \mathrm{O}_{8}$ on $\mathrm{TiO}_{2}$ for selective catalytic reduction of $\mathrm{NO}_{\mathrm{X}}$ with $\mathrm{NH}_{3}$. Appl. Catal. A Gen. 2019, 570, 355-366. [CrossRef]

20. Ding, Y.Q.; Wu, Q.Q.; Li, B.; Guo, Y.L.; Guo, Y.; Wang, Y.S.; Wang, L.; Zhan, W.C. Superior catalytic activity of a Pd catalyst in methane combustion by fine-tuning the phase of ceria-zirconia support. Appl. Catal. $B$ Environ. 2020, 266, 118631. [CrossRef]

21. Li, Y.; Cheng, H.; Li, D.; Qin, Y.; Xie, Y.; Wang, S. ChemInform Abstract: $\mathrm{WO}_{3} / \mathrm{CeO}_{2}-\mathrm{ZrO}_{2}$, a Promising Catalyst for Selective Catalytic Reduction (SCR) of $\mathrm{NO}_{x}$ with $\mathrm{NH}_{3}$ in Diesel Exhaust. Chem. Commun. 2008, 12, 1470-1472. [CrossRef] [PubMed]

22. Shen, B.; Wang, Y.; Wang, F.; Liu, T. The effect of Ce-Zr on $\mathrm{NH}_{3}-\mathrm{SCR}$ activity over $\mathrm{MnO}_{x}(0.6) / \mathrm{Ce}_{0.5} \mathrm{Zr}_{0.5} \mathrm{O}_{2}$ at low temperature. Chem. Eng. J. 2014, 236, 171-180. [CrossRef]

23. Ning, P.; Song, Z.; Li, H.; Zhang, Q.; Liu, X.; Zhang, J.; Tang, X.; Huang, Z. Selective catalytic reduction of $\mathrm{NO}$ with $\mathrm{NH}_{3}$ over $\mathrm{CeO}_{2}-\mathrm{ZrO}_{2}-\mathrm{WO}_{3}$ catalysts prepared by different methods. Appl. Surf. Sci. 2014, 236, 171-180. [CrossRef]

24. Ding, S.; Liu, F.; Shi, X.; Liu, K.; Lian, Z.; Xie, L.; He, H. Significant Promotion Effect of Mo Additive on a Novel Ce-Zr Mixed Oxide Catalyst for the Selective Catalytic Reduction of NOx with $\mathrm{NH}_{3}$. ACS Appl. Mater. Interfaces 2015, 7, 9497-9506. [CrossRef]

25. Hu, H.; Zha, K.; Li, H.; Shi, L.; Zhang, D. In situ DRIFTs investigation of the reaction mechanism over $\mathrm{MnO}_{\mathrm{x}}-\mathrm{MO}_{\mathrm{y}} / \mathrm{Ce}_{0.75} \mathrm{Zr}_{0.25} \mathrm{O}_{2}(\mathrm{M}=\mathrm{Fe}, \mathrm{Co}, \mathrm{Ni}, \mathrm{Cu})$ for the selective catalytic reduction of $\mathrm{NO}_{\mathrm{x}}$ with $\mathrm{NH}_{3}$. Appl. Surf. Sci. 2016, 387, 921-928. [CrossRef]

26. Peng, Y.; Wang, C.; $\mathrm{Li}$, J. Structure-activity relationship of $\mathrm{VO}_{x} / \mathrm{CeO}_{2}$ nanorod for $\mathrm{NO}$ removal with ammonia. Appl. Catal. B Environ. 2014, 144, 538-546. [CrossRef]

27. Peng, Y.; Li, J.; Huang, X.; Li, X.; Su, W.; Sun, X.; Wang, D.; Hao, J. Deactivation mechanism of potassium on the $\mathrm{V}_{2} \mathrm{O}_{5} / \mathrm{CeO}_{2}$ catalysts for SCR reaction: Acidity, reducibility and adsorbed-NOx. Environ. Sci. Technol. 2014, 48, 4515-4520. [CrossRef]

28. Zhang, L.; Li, L.; Gao, Y.; Yao, X.; Ge, C.; Gao, F.; Deng, Y.; Tang, C.; Dong, L. Getting insight into the influence of $\mathrm{SO}_{2}$ on $\mathrm{TiO}_{2} / \mathrm{CeO}_{2}$ for the selective catalytic reduction of $\mathrm{NO}$ by $\mathrm{NH}_{3}$. Appl. Catal. B Environ. 2015, 165, 589-598. [CrossRef]

29. Xu, H.; Sun, M.; Liu, S.; Li, Y.; Wang, J.; Chen, Y. Effect of the calcination temperature of cerium-zirconium mixed oxides on the structure and catalytic performance of $\mathrm{WO}_{3} / \mathrm{CeZrO}_{2}$ monolithic catalyst for selective catalytic reduction of $\mathrm{NO}_{x}$ with $\mathrm{NH}_{3}$. RSC Adv. 2017, 7, 24177-24187. [CrossRef]

30. Chen, Z.; Si, Z.; Cao, L.; Wu, X.; Ran, R.; Weng, D. Decomposition behavior of ammonium nitrate on ceria catalysts and its role in the $\mathrm{NH}_{3}$-SCR reaction. Catal. Sci. Technol. 2017, 7, 2531-2541. [CrossRef]

31. Huang, Z.; Zhu, Z.; Liu, Z. Combined effect of $\mathrm{H}_{2} \mathrm{O}$ and $\mathrm{SO}_{2}$ on $\mathrm{V}_{2} \mathrm{O}_{5} / \mathrm{AC}$ catalysts for $\mathrm{NO}$ reduction with ammonia at lower temperatures. Appl. Catal. B Environ. 2002, 39, 361-368. [CrossRef]

32. Wang, Z.; Guo, R.; Shi, X.; Pan, W.; Liu, J.; Sun, X.; Liu, S.; Liu, X.; Qin, H. The enhanced performance of $\mathrm{Sb}$-modified $\mathrm{Cu} / \mathrm{TiO}_{2}$ catalyst for selective catalytic reduction of $\mathrm{NOx}$ with $\mathrm{NH}_{3}$. Appl. Surf. Sci. 2019, 475, 334-341. [CrossRef]

33. Wang, Z.; Huang, Z.P.; Brosnahan, J.T.; Zhang, S.; Guo, Y.L.; Guo, Y.; Wang, L.; Wang, Y.S.; Zhan, W.C. $\mathrm{Ru} / \mathrm{CeO}_{2}$ Catalyst with Optimized $\mathrm{CeO}_{2}$ Support Morphology and Surface Facets for Propane Combustion. Environ. Sci. Technol. 2019, 53, 5349-5358. [CrossRef] [PubMed]

34. Ali, S.; Chen, L.; Yuan, F.; Li, R.; Zhang, T.; Bakhtiar, S.H.; Leng, X.; Niu, X.; Zhu, Y. Synergistic effect between copper and cerium on the performance of $\mathrm{Cu}_{x}-\mathrm{Ce}_{0.5-x}-\mathrm{Zr}_{0.5}(x=0.1-0.5)$ oxides catalysts for selective catalytic reduction of NO with ammonia. Appl. Catal. B Environ. 2017, 210, 223-234. [CrossRef]

35. Guan, B.; Lin, H.; Zhu, L.; Huang, Z. Selective Catalytic Reduction of $\mathrm{NO}_{x}$ with $\mathrm{NH}_{3}$ over Mn, Ce Substitution $\mathrm{Ti}_{0.9} \mathrm{~V}_{0.1} \mathrm{O}_{2-\delta}$ Nanocomposites Catalysts Prepared by Self-Propagating High-Temperature Synthesis Method. J. Phys. Chem. C 2011, 115, 12850-12863. [CrossRef]

36. Carja, G.; Kameshima, Y.; Okada, K.; Madhusoodana, C.D. Mn-Ce/ZSM5 as a new superior catalyst for NO reduction with $\mathrm{NH}_{3}$. Appl. Catal. B Environ. 2007, 73, 60-64. [CrossRef]

37. Xu, H.; Zhang, Q.; Qiu, C.; Lin, T.; Gong, M.; Chen, Y. Tungsten modified $\mathrm{MnO}_{x}-\mathrm{CeO}_{2} / \mathrm{ZrO}_{2}$ monolith catalysts for selective catalytic reduction of $\mathrm{NO}_{x}$ with ammonia. Chem. Eng. Sci. 2012, 76, 120-128. [CrossRef] 
38. Liu, Z.; Yi, Y.; Zhang, S.; Zhu, T.; Zhu, J.; Wang, J. Selective catalytic reduction of $\mathrm{NO}_{x}$ with $\mathrm{NH}_{3}$ over Mn-Ce mixed oxide catalyst at low temperatures. Catal. Today 2013, 216, 76-81. [CrossRef]

39. Cheng, Y.; Song, W.; Liu, J.; Zheng, H.; Zhao, Z.; Xu, C.; Wei, Y.; Hensen, E. Simultaneous $\mathrm{NO}_{x}$ and Particulate Matter Removal from Diesel Exhaust by Hierarchical Fe-Doped Ce-Zr Oxide. ACS Catal. 2017, 7, 3883-3892. [CrossRef]

40. Liu, Z.; Liu, H.; Zeng, H.; Xu, Q. A novel Ce-Sb binary oxide catalyst for the selective catalytic reduction of NOx with $\mathrm{NH}_{3}$. Catal. Sci. Technol. 2016, 6, 8063-8071. [CrossRef]

41. Adamowska, M.; Krzton, A.; Najbar, M.; Costa, P.D. DRIFT study of the interaction of $\mathrm{NO}$ and $\mathrm{O}_{2}$ with the surface of $\mathrm{Ce}_{0.62} \mathrm{Zr}_{0.38} \mathrm{O}_{2}$ as deNO${ }_{x}$ catalyst. Catal. Today 2008, 137, 288-291. [CrossRef]

42. Meng, D.; Zhan, W.; Guo, Y.; Guo, Y.; Wang, Y.; Wang, L.; Lu, G. A highly effective catalyst of Sm-Mn mixed oxide for the selective catalytic reduction of $\mathrm{NO}_{x}$ with ammonia: Effect of the calcination temperature. J. Mol. Catal. A Chem. 2016, 420, 272-281. [CrossRef]

43. Shao, C.; Liu, X.; Meng, D.; Xu, Q.; Guo, Y.; Guo, Y.; Zhan, W.; Wang, L.; Lu, G. Catalytic performance of $\mathrm{Co}-\mathrm{Fe}$ mixed oxide for $\mathrm{NH}_{3}$-SCR reaction and the promotional role of cobalt. RSC Adv. 2016, 6, 66169-66179. [CrossRef]

44. Liu, F.; Shan, W.; Lian, Z.; Xie, L.; Yang, W.; He, H. Novel MnWOx catalyst with remarkable performance for low temperature $\mathrm{NH}_{3}$-SCR of NOx. Catal. Sci. Technol. 2013, 3, 2699-2707. [CrossRef]

45. Chen, L.; $\mathrm{Si}, \mathrm{Z}$.; Wu, X.; Weng, D. DRIFT Study of $\mathrm{CuO}-\mathrm{CeO}_{2}-\mathrm{TiO}_{2}$ Mixed Oxides for NOx Reduction with $\mathrm{NH}_{3}$ at Low Temperatures. ACS Appl. Mater. Interfaces 2014, 6, 8134-8145. [CrossRef] [PubMed]

46. Onfroy, T.; Clet, G.; Houalla, M. Correlations between Acidity, Surface Structure, and Catalytic Activity of Niobium Oxide Supported on Zirconia. J. Phys. Chem. B 2005, 109, 14588-14594. [CrossRef] [PubMed]

47. Ma, Z.; Wu, X.; Si, Z.; Weng, D.; Ma, J.; Xu, T. Impacts of niobia loading on active sites and surface acidity in $\mathrm{NbO}_{x} / \mathrm{CeO}_{2}-\mathrm{ZrO}_{2} \mathrm{NH}_{3}-\mathrm{SCR}$ catalysts. Appl. Catal. B Environ. 2015, 179, 380-394. [CrossRef]

48. Zuo, J.; Chen, Z.; Wang, F.; Yu, Y.; Wang, L.; Li, X. Low-Temperature Selective Catalytic Reduction of NOx with $\mathrm{NH}_{3}$ over Novel Mn-Zr Mixed Oxide Catalysts. Ind. Eng. Chem. Res. 2014, 53, 2647-2655. [CrossRef]

49. Roy, S.; Hegde, M.S.; Madras, G. Catalysis for NOx abatement. Appl. Eng. 2009, 86, 2283-2297. [CrossRef]

50. Lee, K.J.; Kumar, P.A.; Maqbool, M.S.; Rao, K.N.; Song, K.H.; Ha, H.P. Ceria added Sb-V $\mathrm{V}_{2} \mathrm{O}_{5} / \mathrm{TiO}_{2}$ catalysts for low temperature $\mathrm{NH}_{3}$ SCR: Physico-chemical properties and catalytic activity. Appl. Catal. B Environ. 2013, 142-143, 705-717. [CrossRef]

51. Li, L.; Zhang, L.; Ma, K.; Zou, W.; Cao, Y.; Xiong, Y.; Tang, C.; Dong, L. Ultra-low loading of copper modified $\mathrm{TiO}_{2} / \mathrm{CeO}_{2}$ catalysts for low-temperature selective catalytic reduction of $\mathrm{NO}$ by $\mathrm{NH}_{3}$. Appl. Catal. B Environ. 2017, 207, 366-375. [CrossRef]

52. Shen, Y.; Zhu, S.; Qiu, T.; Shen, S. A novel catalyst of $\mathrm{CeO}_{2} / \mathrm{Al}_{2} \mathrm{O}_{3}$ for selective catalytic reduction of $\mathrm{NO}$ by $\mathrm{NH}_{3}$. Catal. Commun. 2009, 11, 20-23. [CrossRef]

53. Hu, W.; Zhang, Y.; Liu, S.; Zheng, C.; Gao, X.; Nova, I.; Tronconi, E. Improvement in activity and alkali resistance of a novel V-Ce( $\left(\mathrm{SO}_{4}\right)_{2}$ /Ti catalyst for selective catalytic reduction of $\mathrm{NO}$ with $\mathrm{NH}_{3}$. Appl. Catal. B Environ. 2017, 206, 449-460. [CrossRef]

54. Nam, K.B.; Kwon, D.W.; Hong, S.C. DRIFT study on promotion effects of tungsten-modified Mn/Ce/Ti catalysts for the SCR reaction at low-temperature. Appl. Catal. A Gen. 2017, 542, 55-62. [CrossRef]

55. Kumar, P.A.; Jeong, Y.E.; Ha, H.P. Low temperature $\mathrm{NH}_{3}-\mathrm{SCR}$ activity enhancement of antimony promoted vanadia-ceria catalyst. Catal. Today 2017, 293-294, 61-72. [CrossRef]

56. Yang, N.; Guo, R.; Pan, W.; Chen, Q.; Wang, Q.; Lu, C. The promotion effect of Sb on the Na resistance of $\mathrm{Mn} / \mathrm{TiO}_{2}$ catalyst for selective catalytic reduction of $\mathrm{NO}$ with $\mathrm{NH}_{3}$. Fuel 2016, 169, 87-92. [CrossRef]

57. Matrails, H.K.; Ciardelli, M.; Ruwet, M.; Grange, P. Vanadia Catalysts Supported on Mixed $\mathrm{TiO}_{2}-\mathrm{Al}_{2} \mathrm{O}_{3}$ Supports: Effect of Composition on the Structure and Acidity. J. Catal. 1995, 157, 368-379. [CrossRef]

58. Amiridis, M.D.; Duevel, R.V.; Wachs, I.E. The effect of metal oxide additives on the activity of $\mathrm{V}_{2} \mathrm{O}_{5} / \mathrm{TiO}_{2}$ catalysts for the selective catalytic reduction of nitric oxide by ammonia. Appl. Catal. B Environ. 1999, 20, 111-122. [CrossRef]

59. Liu, Y.; Gu, T.; Weng, X.; Wang, Y.; Wu, Z.; Wang, H. DRIFT Studies on the Selectivity Promotion Mechanism of Ca-Modified Ce-Mn/TiO 2 Catalysts for Low-Temperature NO Reduction with $\mathrm{NH}_{3}$. J. Phys. Chem. C 2012, 116, 16582-16592. [CrossRef] 
60. Jiang, B.; Li, Z.; Lee, S. Mechanism study of the promotional effect of $\mathrm{O}_{2}$ on low-temperature SCR reaction on $\mathrm{Fe}-\mathrm{Mn} / \mathrm{TiO}_{2}$ by DRIFT. Chem. Eng. J. 2013, 225, 52-58. [CrossRef]

61. Ma, Z.; Xu, R.; Yang, C.; Wei, W.; Li, W.; Sun, Y. Preparation and Surface Properties of Different Zirconia Polymorphs. Acta Phys.-Chim. Sin. 2004, 20, 1221-1225.

(C) 2020 by the authors. Licensee MDPI, Basel, Switzerland. This article is an open access article distributed under the terms and conditions of the Creative Commons Attribution (CC BY) license (http://creativecommons.org/licenses/by/4.0/). 